\title{
MESOZOIC-CENOZOIC PALEOGEOGRAPHIC AND GEODYNAMIC EVOLUTION OF SOUTHERN SOUTH AMERICA
}

\author{
MIGUEL A. ULIANA* and KEVIN T. BIDDLE**
}

\begin{abstract}
In this presentation, we compare the paleogeographic evolution of continental South America with the established plate tectonic history of the oceanic crust of the South American and African Plates. Major paleogeographic changes that have occurred in the last 200 million years are illustrated by reconstructions at $200,160,120,100,70,50,20$, and $5 \mathrm{Ma}$. These reconstructions show location and type of magmatic activity, types and amounts of subsidence, and transgressions and regressions of shorelines. The latter are compared with proposed eustatic sea-level changes. The sequence of events documented by the reconstructions begins in the mid-late Triassic with the development of successor troughs and intra-plate domes and sags that represent the prelude to the rupture of Gondwanaland. Extension continued through the Late Jurassic resulting in widespread faulting and intra-plate volcanism. Large-scale drift occurred by the Early Cretaceous (late Neocomian) accompanied by the formation of epicontinental rifts and sags, and a well-defined magmatic arc along the western margin of South America. In the mid-Cretaceous the Atlantic Basin was well developed and rimmed by trailing-margin sedimentary prisms, and global changes in plate motions led to the reorganization of the subduction system along the Pacific margin of South America. The Late Cretaceous, a time of relative tectonic quiescence in southern South America, recorded the maximum flooding of the continent by Atlantic waters. Plate tectonic reorganization in the Paleogene introduced new patterns of Andean deformation and magmatism, and coincided with general marine retreat. Magmatic arc buildup and renewed marine flooding followed in the early Neogene, with the late Neogene being dominated by pronounced shortening, Cordilleran uplift, and marine withdrawal.
\end{abstract}

RESUMO Evoluçāo paleogeográfica e geodinâmica mesozoico-cenozoica da porçāo meridional da América do Sul. A evolução paleogeográfica do continente sul-americano é comparada com a história tectônica das placas Sul-Americana e Africana. São ilustradas as principais mudanças paleogeográficas ocorridas durante os últimos 200 milhōes de anos através de reconstruçōes esquemáticas correspondentes a 200, $160,120,100,70,50,20$ e $5 \mathrm{Ma}$. As reconstruçōes servem como base para analisar a localizaçäo e o tipo de atividade magmática, os tipos e a magnitude da subsidência, e as transgressőes e as regressōes na linha de costa. Estas últimas são comparadas com as variaçōes eustáticas globais propostas por outros autores. A seqüência de eventos documentada na reconstruçâo começa no Meso-Neotriássico com o desenvolvimento de fossas tectônicas e de domos e sinéclises de intraplaca, que representava o prelúdio à ruptura do supercontinente Gondwana. A extensão continuou até o Neojurássico por importante falhamento e vulcanismos de intraplaca. Durante o Eocretáceo registrou-se deriva continental em grande escala (Neocomiano), acompanhada pela formaçāo de riftes e sinéclises epicontinentais e um arco magmático bem definido ao longo da margem ocidental da América do Sul. Na metade do Cretáceo, a bacia do Oceano Atlântico estava bem desenvolvida e margeada por cunhas sedimentares de margem passivo. Mudanças globais no deslocarnento das placas levaram a uma reorgaizaçāo do sistema de subducção implantado sobre a margem pacífica de América do Sul. O Neocretáceo, um período de relativa quietude tectônica na América do Sul meridional, registrou a penetração máxima das águas oceânicas sobre o continente. Uma nova reorganização tectônica đurante o Paleogeno modificou uma vez mais os padrōes de deformaçāo e magmatismo, e foi coincidente com uma importante retirada do mar. Durante o Eogeno, ocorreram condiçōes que induziram uma renovada atividade no arco magmático e uma importante invasăo marinha, enquanto o Neogeno esteve caracterizado por um pronunciado encurtamento reginal, elevação da cordilheira e retirada do mar.

INTRODUCTION During the Mesozoic and Cenozoic, the tectonic development of southern South America was controlled by a complicated subduction regime along its western margin and the evolving spreading center of the Mid-Atlantic Ridge along its eastern margin. Processes associated with activity along these two plate boundaries provided the first-order controls on subsidence and uplift in the area, and thus controlled the sites available for sediment accumulation. Both long- and short-term sea-level variations were superimposed on the tectonic framework and modified the paleogeography of the continent. Here, we discuss the interplay of tectonics and sea-level changes by presenting eight paleogeographic reconstructions of southern South America that show the distribution of areas of nonmarine and marine sedimentation and associated igneous activity. The reconstructions are at $200,160,120,100,70,50,20$, and 5 Ma (Figs. 1-8). The text that accompanies each reconstruction discusses the key tectonic and magmatic events, the distribution and type of sedimentary rocks, and the relationship with postulated global and local sea-level cycles.

The reconstructions are a compilation of information derived from the literature and our own work on the sedimentary basins of southern South America. Each map represents a variable (but short as possible) time around the own age: local paleogeography may be more complicated because of simplification due to the small size of the maps, stratigraphic interfingering, and lack of stratigraphic precision in some areas.

Mid-Late Triassic successor troughs, intraplate domes and sags: Prelude to the disruption of Gondwanaland (Figure 1) Epicratonic Triassic deposits are preserved in the large Chaco-Paraná basin in Uruguay, NE Argentina, E Paraguay, and S Brazil (Harrington 1962), and also in the smaller "Fosa de Entre Ríos" of S Bolivia and NW Argentina (Ahlfeld \& Branisa 1960).

All these accumulations are separated from the Paleozoic (Gondwana) deposits by a surface of regional truncation (Ahlfeld \& Branisa 1960, Padula 1972a, Soares 1981). Depositional sites were much reduced with respect to the earlier Permo-Carboniferous Gondwana sequences. Thickness patterns (Padula op. cit, Soares op. cit.) are quite regular and outline a picture of interior sag sedimentation. The existence of distinct depocenters segmented by internal 


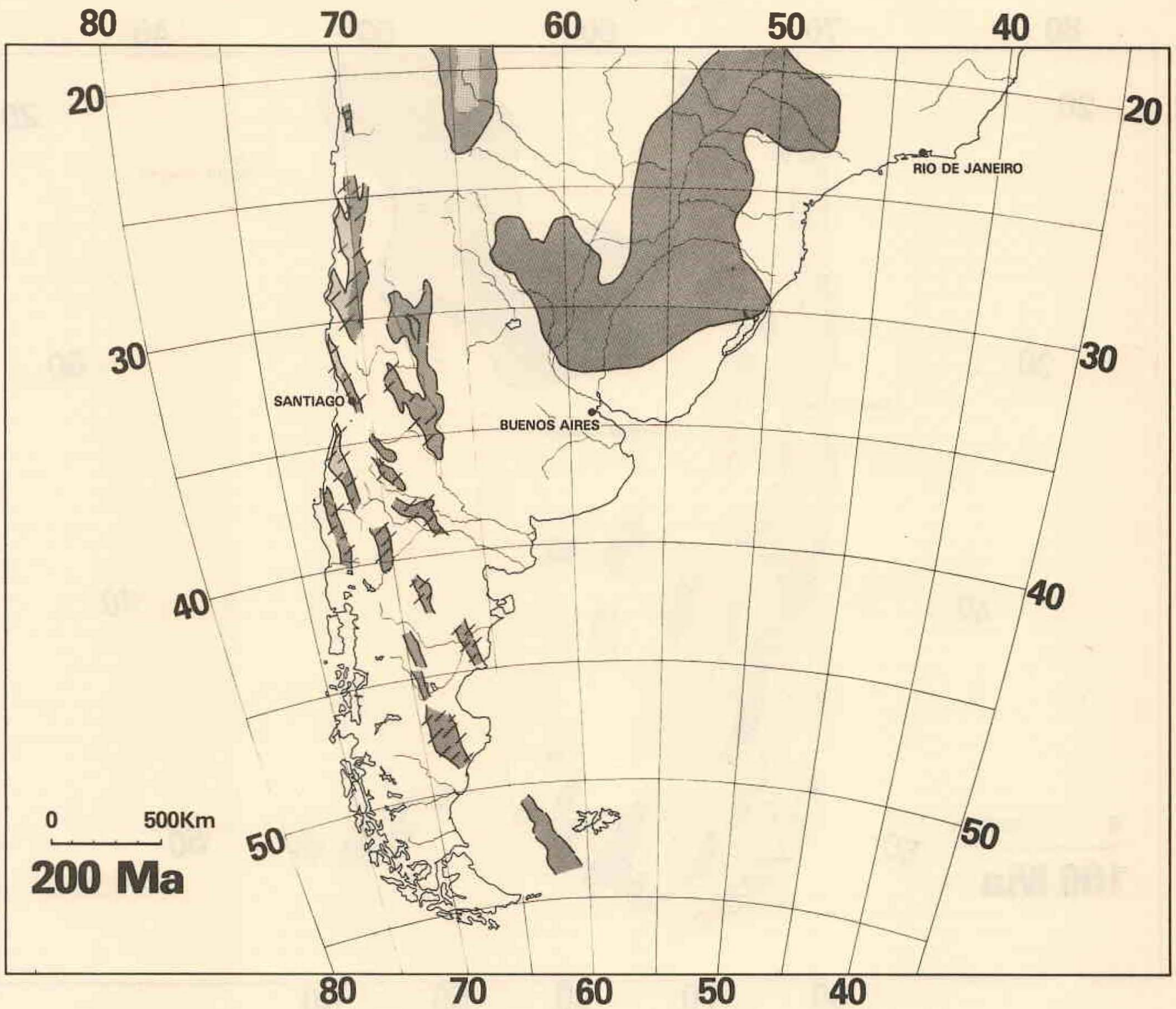

Figure 1 - $200 \mathrm{Ma}$ (mid-Late Triassic) paleogeographic reconstruction of southern South America showing the distribution of mid-Late Triassic successor troughs and sags. Dark grey pattern represents areas of nonmarine sedimentation; lighter pattern represents areas of marine sedimentation. Lined areas indicate regions affected by igneous activity. See text for discussion

highs and bounded by broad warps reveals a tectonic habitat characterized by large arches and regional sags, and is well documented in S Brazil (Asmus 1978), east-central Brazil (Asmus \& Porto 1980), S and W Africa (Le Bas 1971, Burke \& Whiteman 1973, Rust 1975), Namibia (Martin 1976, Siedner \& Mitchell 1976), and N Argentina (Bianucci \& Homovc 1982). A $180 \mathrm{Ma}$ isotopic resetting of the Paleozoic rccks in the Paraná basin (Thomas Fo et al. 1976) is considered to represent the thermal signature of this Early Mesozoic tectonic event (Asmus \& Baisch 1983).

Sedimentary fill of the Chaco-Paraná Triassic sags is a non-marine clastic succession of cross-stratified sandstones and red to brown mudstones, deposited in channels and flood-plain settings drained by meandering and locally anastomosing fluvial systems (Soares 1981). The sequence in S Bolivia and NW Argentina also includes a thin marine tongue (Harrington 1962) and evaporites. The vertical succession of non-marine clastics, marine limestones, and evaporites (Ahlfeld \& Branisa 1960) resembles the Triassic sequences of NW Europe (Wurster 1965, Gwinner 1978, p. 130-136, and the references therein) and the Middle East (Murris 1980) and suggests a strong eustatic control on the lithofacies development.

Mid-Late Triassic accumulations in central Chile, west-central and southern Argentina were deposited within a complex system of rapidly subsiding and fault-bounded troughs with NNW-SSE orientation (Rolleri \& Criado 1968, Charrier 1979, Criado 1979, deGuisto et al. 1980). Almost everywhere the Triassic rocks rest on a sharp lithologic and structural discontinuity. Abundant silicic to intermediate volcanic and volcaniclastic rocks (Charrier, op. cit., Criado op. cit., Stipanicic 1983, Cortés 1981, Naranjo et al. 1982) record significant syntectonic magmatic activity.

Sequences in Chile start with continental deposits followed by conspicuous marine members (Cecioni \& Westermann 1968, Charrier op. cit., Chong \& Hillebrandt 1985). A Late Triassic increase in marine influence and the stratigraphic continuity across the Triassic-Jurassic boundary (Chong \& 


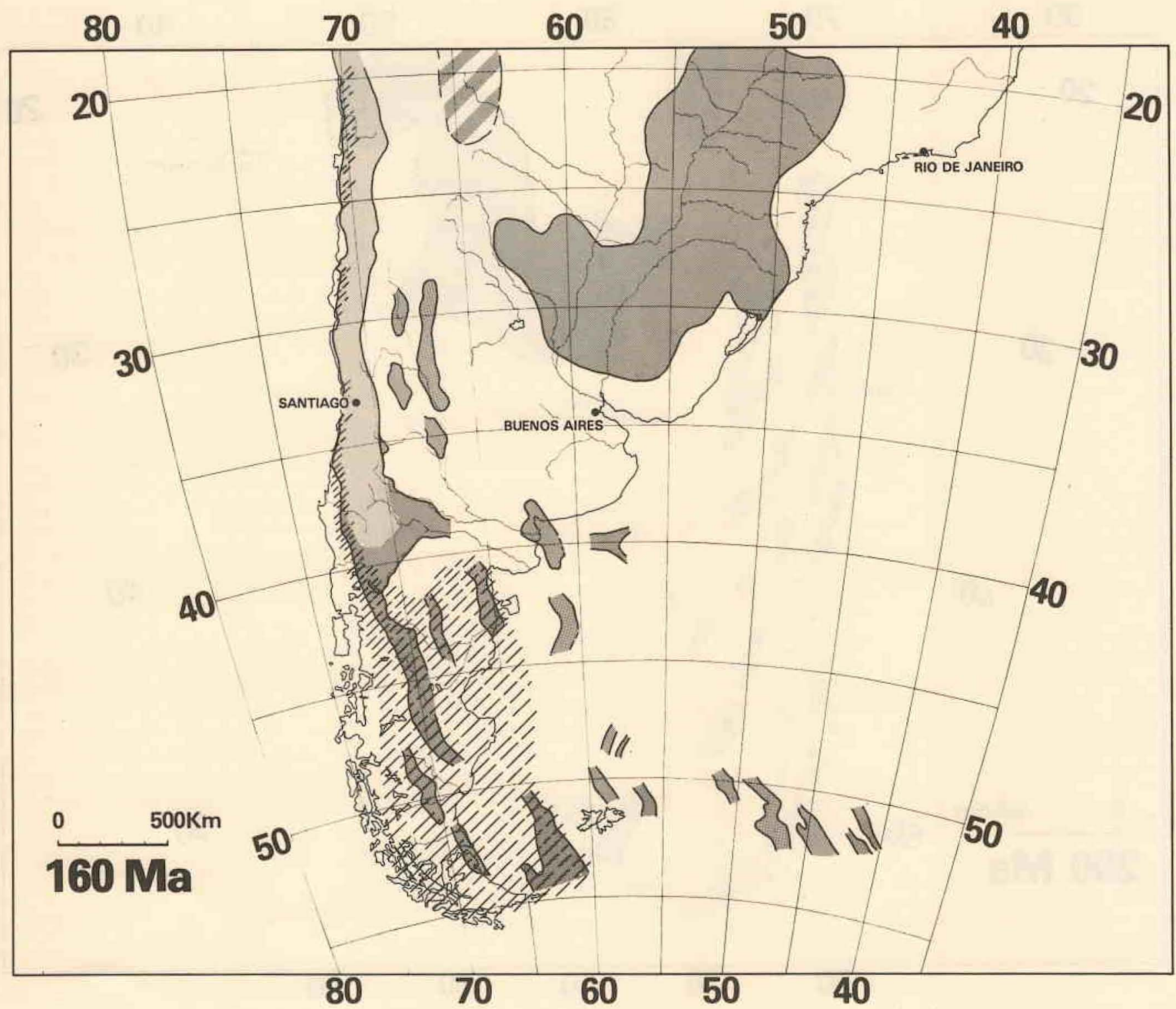

Figure 2 - $160 \mathrm{Ma}$ (Middle Jurassic) paleogeographic reconstruction illustrating Jurassic extension, volcanism, and the onset of continental breakup. Key as in figure 1

Hillebrandt 1985) deviate from the global eustatic trend and implie a local effect attributable to high rates of fault-controlled subsidence.

The mid-Late Tríassic successions in west-central Argentina are entirely non marine. They show a fining-upward basal section rich in volcaniclastic rocks, Followed by extensive organic-rich shales that were deposited in stratified lakes, in turn followed by a shallowing-upward package capped by red beds (Yrigoyen \& Stover 1969, Stipanicic 1983). The south-eastern extensions of the graben system in Patagonia also contain non-marine facies (occasionally red and coarse grained, Mombrú \& Uliana 1979, Turner \& Cazau 1979, deGuisto et al. 1980), with local development of thick silicic volcanic rocks (Cortés 1981, Llambías \& Rapela 1984). The probable occurrence of Triassic graben fill in the Magallanes and Malvinas basins outlined on the basis of seismic control (Biddle et al. 1986, and unpublished data).

The Chilean-Argentine system of mid-Late Triassic fault-bound depocenters can be described as a series of successor troughs developed on top of collapsed portions of the late Paleozoic fore-arc and arc terranes. Most authors attribute the Triassic troughs to an extensional regime (Rolleri \& Criado, 1968, Chong \& Hillebrandt 1985) or to transtensional conditions (Criado et al. 1981). The rate and style of subduction along the Triassic paleo-Pacific margin of South America is difficult to assess. Jensen (1976) and Charrier (1979) suggest that magmatism was confined to several volcanic chains bounding the depositional troughs with trends oblique to the margin, rather than a single, continuous arc.

Paleogeographic reconstruction of the mid-Late Triassic basins provides a picture that is in concert with events associated with the pre-breakup stage of supercontinent. A 50 Ma period of Gondwanidian quasi-stasis (from late Permian to mid Triassic, Valencio \& Vilas 1976), may have promoted strong sub-lithosphere heat buildup (Worsley et al. 1984). The resultant thermal subsidence pattern could have provided the basin and swell structure that controlled the Triassic sedimentation in the South-American Chaco-Paraná basins 
and the African Karroo-type depocenters (Rust 1975).

Heat buildup and consequent high continental freeboard (Worsley et al. 1984) provide a good explanation to the dominance of non-marine facies shown by the southern South-American and south African Triassic sequences.

Mid-Late Jurassic Extension and Intraplate Vulcanism: Onset of the Continental Breakup (Figure 2) The Paraná and Chaco basins in southern Brazil and NE Argentina continued to receive clastics under desert conditions dominated by eolian regimes (Soares 1981), while the Andean segment of Bolivia was the site of non-marine clastic and marine carbonate sedimentation (Sempere 1986, Sempere et al. 1986). Early Jurassic eustatic rise induced regional flooding (Cisternas 1979, Chong \& Hillebrandt 1985) beyond the boundaries of the Triassic troughs, and lead to the development of a linear marine belt fringing the continental slab in northern and central Chile (Cecioni 1970, Riccardi 1983). Coeval subsidence behind this belt diminished drastically in the Cuyo and Bolsones system of grabens in west-central Argentina, where Jurassic deposition is represented by a thin sequence of redbeds locally associated with the basaltic flows (González 1971, Yrigoyen 1975a, Criado 1979). The sections in northern and central Chile show a different magmatic habitat, consistent with the inception and growth of a magmatic arc (Davidson \& Godoy 1976, Cisternas \& Vicente 1976, Jensen et al. 1976, Cisternas 1979). Following the early Liassic marine flooding of the plate edge, middle Lias sequences submarine volcanic rocks punctuated by sedimentary interbeds (Davidson \& Godoy, 1976, Naranjo et al. 1982, Riccardi 1983) indicating the development of an island arc complex; and finally the middle-Upper Jurassic sequences show the existence of an essentially continuous and emergent volcanic feature (Jensen et al. 1976, Cisternas op. cit.). In northern and central Patagonia the influence of Triassic structural grain and fault-induced subsidence patterns is documented by the NNW-SSE orientation of the marine incursions (Groeber 1953, Lesta \& Ferello 1972, Riccardi op. cit.). All over Patagonia the belt of active extension and fault-driven subsidence became wider by enlargement of the graben system and appearance of new fault-bound troughs. Positive hydrologic balance favored the development of lake systems, locally filled with organic rich shales and fresh-water limestones (Feruglio 1949, Tasch \& Volkheimer 1970, Cortiñas 1984). The subaerial portions of the depositional system record the occurrence of syntectonic (bimodal) volcanism (Lesta \& Ferello op. cit., deGuisto et al. 1980, Cortinãs $o p$. cit.), with peak activity around $165-155 \mathrm{Ma}$ (Gust et al. 1985). To a large extent the Jurassic magmatic activity in Patagonia has been attributed to crustal anatexis (Bruhm et al. 1978, Baker et al. 1981, Gust et al. op. cit.), although synchronous subduction-derived calcalkalic magmatism at plate-edge positions has been documented within the North-Patagonic Andes (Haller 1985). In several places of north-central Patagonia and also in the Andean belt of north-central Chile, vertical accretion of the erupted material reduced marine influence and led to wider non-marine deposition (Cisternas 1979, Riccardi 1983). Over the Patagonic Andes and the present southern fringe of South America, regional extension and subsidence were persistent and by Late Jurassic allowed massive flooding in the Magallanes (Charrier \& Covacevich 1980, Wilson 1983) and Malvinas (Bianchi 1986b) basins, and also over large portions of the Falkland Plateau (Barker \& Dalziel 1976, Ciesielski \& Wise 1977) and the southern tip of Africa (McLachlan \& McMillan 1979, Dingle et al. 1983).

In summary, the Jurassic period was characterized by general persistence of extensional conditions and fault-driven subsidence. The western margin of South America seems to have been the site of active convergence, and the gradual development of a linear arc-backarc system (Mariana type, Munizaga et al. 1985) roughly parallel to the boundary of the continental slab. A large portion of the Gondwana landmass continued to show signs of crustal instability. Although intra-plate extension diminished in west-central Argentina, block faulting was pervasive in Patagonia (Bruhn et al. 1978, Suarez 1979, Thiele \& Hein 1979, Uliana \& Biddle 1987), the Falkland Plateau, and reached the Cape province (Lock 1978, 1980 ) and the present SW African margin (Gerrard \& Smith 1982). Crustal stretching in Patagonia lead to Late Jurassic crustal breakup and opening of the small Rocas Verdes Marginal basin in Southern Chile and Argentina (Dalziel et al. 1974) and ultimately to a large-scale crustal separation and opening of the South Atlantic (Simpson 1977, Rabinowitz \& LaBrecque 1979, Uliana \& Biddle 1987). Widespread magmatic activity of Basin and Range type is recorded in Patagonia (Gust et al. 1985) and to a smaller extent in the conjugate margins off southern and south-western Africa (Dingle et al. 1983). The South American Tobífera magmatic event was coeval with the massive HoachanasStormberg-Lebombo eruptions onshore SW, S, and SE Africa (Britow \& Saggerson 1983, Dingle et al. op. cit.) and with widespread basaltic activity in Antarctica (Schmidt \& Rowley 1986). This Jurassic magmatic paroxism was the immediate predecessor of large-scale Gondwanaland disagregation.

Neocomian rifts, sags, and magmatic arc: continental split and onset of large-scale drift (Figure 3) Those basins close to the western margin of South America continued to accumulate marine deposits. The basins were generally narrow, with a sharp western boundary dominated by volcaniclastics (Skarmeta 1976a, Espinoza Reyes 1986) and an eastern margin bounded by faults (Charrier 1984), or were defined by gradual stratigraphic thinning and onlap onto the foreland (Ramos 1985). Axial positions of these intra-arc and back-arc troughs accommodated anoxic shales (Haller et al. 1981, Espinoza Reyes op. cit.) and local turbidite flows (Ramos \& Palma 1983). Reduced continental freeboard during the Neocomian allowed the marine flooding of large portions of the continental slab in west-central Argentina, SW Patagonia, the Malvinas basin, and the Falkland Plateau. In those areas basinal and shelfal facies belts expanded and sediment dispersal was highly influenced by eustatic oscillations (Legarreta et al. 1981, Mitchum \& Uliana 1985, Biddle et al. 1986).

Large areas of the southern South American interior became a depositional site for non-marine clastic material during the Neocomian. NW. Argentina contains several extensional troughs related to radial ruptures developed on top of earlier Mesozoic thermal domes (Bianucci \& Homovc 1982). These basins were filled by alluvial-fan and fluvial deposits associated with volcanics erupted at graben junctions and along longitudinal faults (Reyes et al. 1976, Bianucci \& Homove op. cit.). The same pattern of red-bed deposition within extensional basins has been documented in the Andean basins of Bolivia (Cherroni 1977, Sempere 1986), in central Argentina (Yrigoyen 1975a, Manoni, 1985), onshore Uruguay (Sprechmann et al. 1981), and the basins buried under the Argentine shelf (Yrigoyen 1975b, Zambrano 1980). A different pattern developed in large areas of central Patagonia, where subsidence during thermal decay of the heat anomaly produced by Triassic-Jurassic rifting favored the accumulation of organic-rich shales and limestones in broad lacustrine systems (Lesta \& Ferello 1972, Cortiñas \& Arbe 1981).

Knowledge of the Neocomian wedges deposited at the margins of the incipient South Atlantic is still incomplete. Rift-valley type deposits are well known in the marginal 


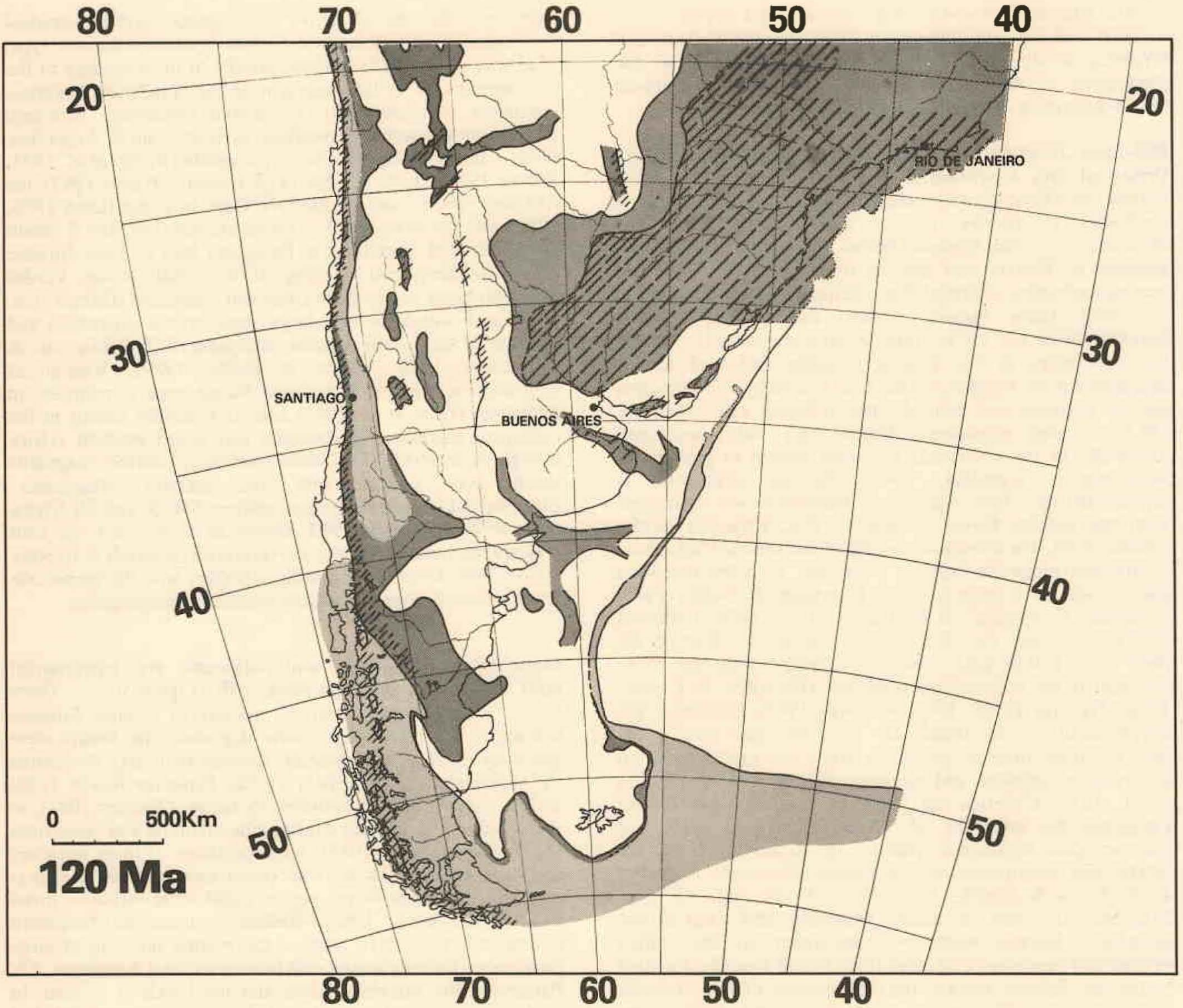

Figure 3 - $120 \mathrm{Ma}$ (Neocomian) paleogeographic reconstruction illustrating Early Cretaceous rifts, sags, and magmatic arc. Key as in figure 1

Campos basin, where only a very limited marine influx was possible (Asmus \& Guazelli 1981) because of paleogeographic restriction. These accumulations were formed by series of alluvial fans feeding lacustrine basins, and display a shoaling-upward trend that culminated in evaporite deposition (deCastro et al. 1981). In the Pelotas and Santos basins off Brazil the early rift fill is areally restricted (Gonçalves $e t$ al. 1979, Asmus \& Baisch 1983). Offshore Argentina exhibits a sizeable sedimentary accumulation associated with rotated basement fault blocks (Jodri \& Lehner 1973). Farther south on the Falkland Plateau the Neocomian deposits are shaly and organic-rich marine accumulations (Barker et al. 1976, Ludwig et al. 1980), deposited as a parallel drape under a pelagic regime.

An area over 1.2 million $\mathrm{km}^{2}$ centered in the Paraná Basin of SE Brazil was covered by thick continental flood basalts. These eruptions were focused on the crest of a pre-rift thermal dome (Asmus 1975, Williams \& Hubbard 1984). The magmatism persisted from 147 to $120 \mathrm{Ma}$, during a time of continental rifting and crustal attenuation (Fodor et al. 1983), and outlined a continuous volcanic province from the Chaco Basin in Argentina and Uruguay (Padula 1972a) to Namibia in southern Africa. Away from the plate margin the lavas are interstratified with intracratonic eolian rocks (Soares 1981).

Late Jurassic to Neocomian sequence record active crustal stretching in areas along the present margins of the South Atlantic. By $130 \mathrm{Ma}$ the first oceanic floor was formed in the South Atlantic (Rabinowitz \& LaBrecque 1979, Gerrard \& Smith 1982). Continental breakup started in the south and propagated northward, but due to low latitudinal position of the pole of opening (Francheteau \& LePichon 1972, Rabinowitz \& LaBrecque op. cit.), the generation of oceanic floor during the Neocomian was limited to position south of the São Paulo-Walvis ridge (Rabinowitz \& LaBrecque op. cit., Asmus \& Braisch 1983). Presumably because a general reorientation of the stress regime leading to the oceanic opening, the South American cratonic platform reacted by development of a new system of interior rifts and by collapse of the Triassic-Jurassic thermal domes ("Wealdenian reactivation" in Almeida 1967). The new extensional 


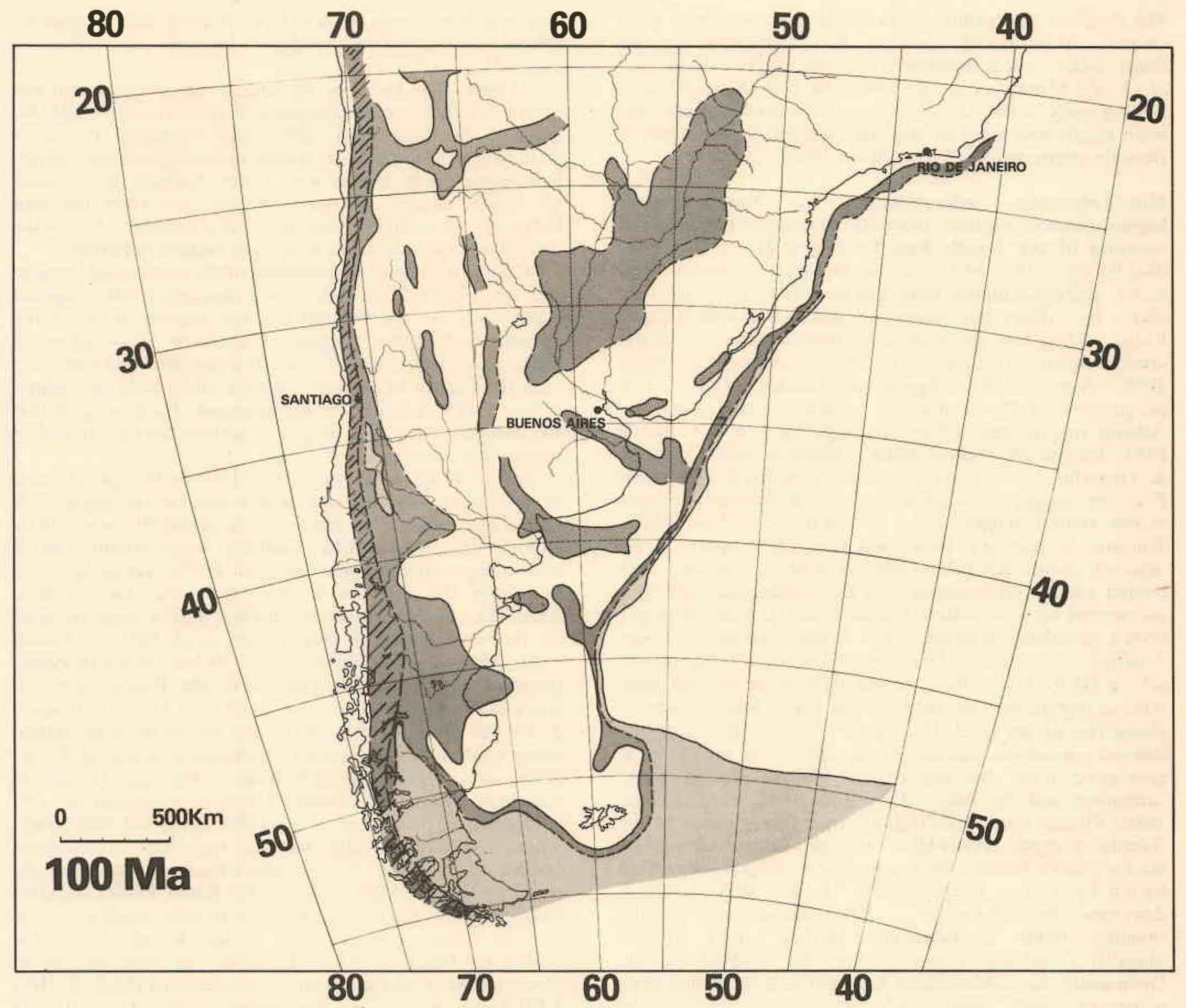

Figure 4-100 Ma (Mid-Cretaceous) paleogeographic reconstruction illustrating mid-Cretaceous adjustments in spreading regime, batholithic emplacement, and full opening of the South Atlantic. Key as in figure 1

ruptures propagated from southern Argentina to southern Brazil and southwest Africa (Brice et al. 1982, Gerrard \& Smith 1982), and also progressed into Uruguay (Sprechmann et al. 1981), central and north-western Argentina (Yrigoyen 1975a, 1975b, Bianucci \& Homove 1982), Paraguay (Degraff 1985), and Bolivia (Fletcher \& Litherland 1981, Avila-Salinas 1986) giving rise to numerous rift basins.

While this renewed rifting was taking place, several of the Triassic-Jurassic fault-bounded troughs became inactive in west-central Argentina, Patagonia, and on the Falkland Plateau, and were dominated by thermally driven subsidence (Gust et al. 1985, Biddle et al. 1986, Uliana \& Biddle 1987). Although the site of active subduction, the western fringe of the South American plate also was controlled by a regime that promoted crustal extension and subsidence in troughs located at intra-arc and back-arc positions (Coira et al. 1982, Espinoza Reyes 1986, Pincheira \& Thiele 1982, Haller \& Lapido 1982, Ramos et al. 1982, Suarez 1979). These arc-related depocenters were in local paleogeographic continuity with some of the thermal sags developed on top of the then less active Triassic-Jurassic rifts, and controlled the location of expanded segments of the Neocomian back-arc embayments and seaways. The magmatic activity over the edge of the plate was calc-alkalic, and the record points the existence of a mostly continuous arc feature from northern Chile to Tierra del Fuego (Thiele \& Hein 1979, Haller \& Lapido 1982, Thiele \& Nasi 1982, Hervé et al. 1984, Espinoza Reyes 1986).

In general concordance with the changes in the rifting patterns, significant variations in the location and character of the magmatic activity are perceptible in South America as well as in south Africa (Dingle et al. 1983). The most notorious change was the waning of the Patagonic extrusions and the inception of the huge tholeiitic volcanic fields in NE Argentina, Brazil, and Namibia (Serra Geral-Kaoko). Outside of that region intra-plate magmatism tended to follow linear trends related to the process of rifting (Reyes et al. 1976, Fletcher \& Litherland 1981, Moya \& Salfity 1982, Avila-Salinas 1986), and also zones along the flanks of the Triassic-Jurassic thermal uplifts (Asmus \& Braisch 1983). 
The tholeiitic to rhyolitic Serra Geral flood volcanics were derived from mantle sources that underwent crystal fractionation and assimilation of crustal material (Bellieni et al. 1984, Mantovani et al. 1985). In NW Argentina and Bolivia many of the rift-related igneous rocks are alkalic, and were locally preceeded by trachytes and carbonatites derived from the upper mantle (Avila-Salinas 1986).

Mid-Cretaceous adjustments in the spreading-subduction regime: batholith emplacement and full opening of the South Atlantic (Figure 4) The areal distribution of the mid-Cretaceous lithofacies reflects several major paleogeographic modifications from previous time slices. By Albian time spreading across the Mid Atlantic Ridge system had produced a continuous band of oceanic crust between Africa and South America (Asmus \& Carvalho 1978, Asmus 1981, Asmus \& Guazelli 1981). The progression of the continental breakup formed a narrow Atlantic marine basin ("Oceanic Stage" in Asmus \& Baisch 1983) fringed by shallow-water carbonate system (Asmus \& Guazelli op. cit.). At this time subsidence of the SE Brazilian margin occurred through gentle basement flexure across coastal hinges (e.g., see Gonçalves et al. 1979, Williams \& Hubbard 1984) and concorrent uplift of the adjacent continental belt (Asmus \& Guazelli op. cit.) with limited marine encroachment on the continental slab. This widespread tectonic pattern indicates that post-rift thermally driven subsidence dominated the Atlantic margin of South America, leading to the development of a passive depositional setting (Drift Stage, for a similar pattern on the conjugate African margin see Gerrard \& Smith, 1983). Mid-Cretaceous global rise of sea level (Haq et al. 1987), coupled with the thermal subsidence, increased accommodation on the shelf generating local drowing of the Albian shallow-water carbonates and fan deltas (Dias-Brito 1982, Pereira et al. 1986, Viviers 1986). The central Argentina segment of the Atlantic margin, meanwhile, remained largely devoid of marine waters, because the basins close to the plate edge were barred by a large marginal ridge (Rolleri 1972, Urien \& Zambrano 1972, Urien et al. 1981). However, a definite flooding trend is detectable farther south in the Magallanes-Malvinas basins and on the Falkland Plateau. Dominantly clastic Neocomian sedimentation was replaced by sequences with high carbonate imput, while the stratified-anoxic early Cretaceous regime was supplanted by open oceanic circulation with a aerobic-disaerobic regime (Biddle et al. 1986) and the appearance of a more diversified and extra basinal invertebrate assemblage (A.C. Riccardi, oral communication, 1987).

A quite different depositional trend is the system of basins related to the Pacific margin of South America. The arc and back-arc depocenters of northern and central Chile document a pronounced marine withdrawal (Thiele \& Nasi 1982). The Neuquén basin became dominated by evaporites and red beds (Digregorio \& Uliana 1980) and the San Jorge Basin lost its marine connection (Aguirre Urreta \& Ramos 1981) with deep-stratified lakes being replaced by shallow-lake alluvial systems (Bianchi 1986a). The overall increase in clastic imput and extent of the non-marine settings was temporally and spatially related to an increase in the magnitude of the arc-related activity (e.g., see Ramos 1978). The trend is thought to reflect a change in the dynamics and geometry of the subduction beneath western South America (Coira et al. 1982, Haller \& Lapido 1982, Munizaga et al. 1985), caused by the rapid Cretaceous spreading postulated by Larson \& Pitman (1972). Widespread evidence of synchronous emplacement of massive batholiths along the Andean belt (Ramos \& Ramos 1979, Munizaga et al. 1985) together with evidences of regional uplift and marine withdrawal are consistent with the development of a lithosphere-scale marginal tumescence arising from heating and magmatism related to subduction at the edge of the plate (e.g., Tobisch et al. 1986).

At intra-plate locations the Chaco-Paraná area stands out because of waning of the magmatic outpourings after $120 \mathrm{Ma}$. Most of the intracratonic depocenters continued to receive clastic debris without major change in the depositional regime. Epeiric marine incursions were limited because the presence of coastal barriers at plate margins, and from northern Patagonia to southern Bolivia and south-eastern Brazil the depositional sites remained under non-marine conditions.

The mid-Cretaceous completion of the continental breakup and onset of full-scale drift was associated with regional adjustments in the thermo-tectonic regime at both the Atlantic and Pacific margins of southern South America. When the timing of mid-Cretaceous magmatism is compared with the history of Atlantic opening and Pacific spreading, several major coincidences are apparent. These suggest that the changes in focus of magmatic activity are closely tied to major plate interactions.

From $130 \mathrm{Ma}$ to approximately $110 \mathrm{Ma}$ the opening pole of the South Atlantic was at low latitude (Rabinowitz \& LaBrecque 1979). This produced an assymetric ocean-floor configuration with a wide southern South Atlantic and a narrow equatorial Atlantic (Simpson 1977). During the same time span the situation in the Pacific was one of slow spreading, coupled with an extensional regime along the edge of the South American plate (Baker et al. 1981 e.g. Frutos 1981, Aberg et al. 1984). At about $110 \mathrm{Ma}$ a series of events occurred almost simultaneously. On the Pacific side, the spreading rate stepped up from $5 \mathrm{~cm} / \mathrm{yr}$ to $18 \mathrm{~cm} / \mathrm{yr}$ (Larson \& Pitman 1972, Frutos 1981) and the convergent system along western South America underwent a profound change (Coira et al. 1982) shifting from a Marianas (Uyeda \& Kanamori 1979) to a Chilean (Uyeda \& Kanamori op. cit.) configuration (Munizaga et al. 1985). Regional emergence, marine withdrawal, and massive batholith emplacement became prominent. Coeval shortening, at least locally developed, induced the closure of the Rocas Verdes marginal basin (Dalziel 1981) and incipient flexural loading in the western Neuquén basin. Most of the deformation in the central and Patagonia Andes, however, may have been due to block tectonics and magmatic emplacement (Thiele \& Hein 1979, Baker et al. op. cit., Aberg et al. op. cit.). About $107 \mathrm{Ma}$ was the time when the eastern tip of the Falkland plateau cleared the apex of south Africa, presumably relaxing some of the mechanical constraints on the South Atlantic spreading system (Simpson op. cit.). This new situation allowed the shift to a more northerly located pole of opening, a change that permitted almost uniform extension along the South Atlantic (Simpson op. cit, Rabinowitz \& LaBrecque op. cit.), and was associated with magmatic quiescence along the South America continental margin. This regime persisted until 80 Ma when the limitations imposed by the equatorial fracture zones and ridges were cleared, allowing a major reorganization of the spreading geometry and the adoption of a rotational pole common to North and South America (Simpson op. cit.). The occurrence of this event was coeval with the reinception of alkalic igneous activity on the African and South American plates (isotopic dates cluster between 80 and $50 \mathrm{Ma}$, Marsh 1973, Asmus \& Guazelli 1981). Some of these rocks were emplaced along the north and north-east margins of the Paraná basin, but many of them are located on lineaments aligned with transform directions and are interpreted to be a result of reactivation of fracture zones caused by stress related to the change of the Cretaceous pole of rotation (Marsh 1973, Fodor et al. 1983). On the Pacific side $85 \mathrm{Ma}$ is known to be the time when the Pacific spreading returned to a slow rate (Larson \& Pitman 1972). This change is considered to have caused the end of the 


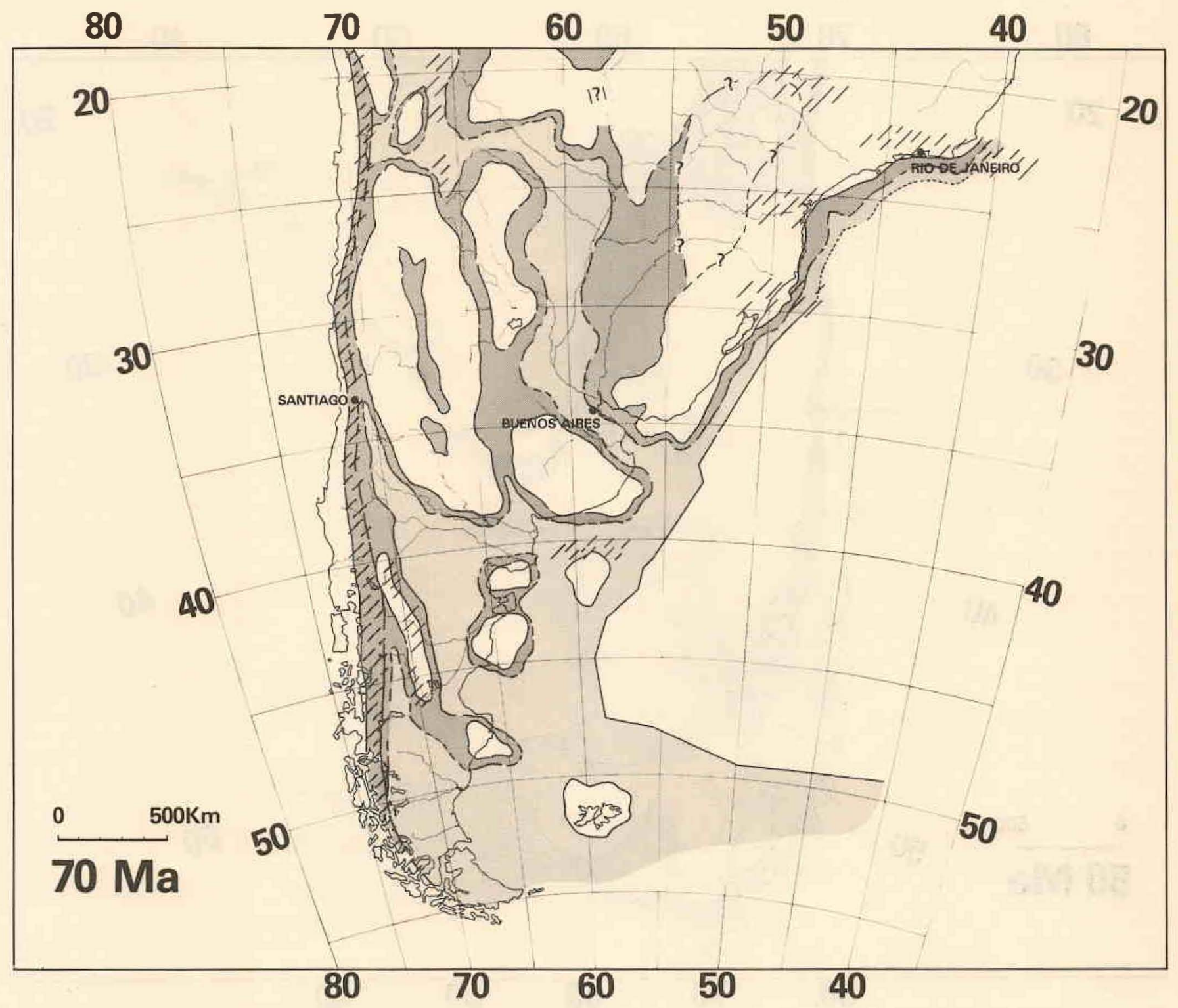

Figure 5 - $70 \mathrm{Ma}$ (Late Cretaceous) paleogeographic reconstruction illustrating tectonic quiescence and acme of epeiric flooding. Key as in figure 1

mid-Cretaceous period of massive batholith emplacement (Haller \& Lapido 1980, 1982) and reestablishment of extensional conditions in the Andean back-arc region. The magmatic expression of the new regime includes $80-70 \mathrm{Ma}$ basalts flows in Patagonia (Franchi \& Page 1980, Baker et al. 1981), and basalt to andesite extrusions related to reactivation of earlier rifts in north-western Argentina and southern Bolivia (Moya \& Salfity 1982, Avila Salinas 1986).

Late Cretaceous tectonic quiescence: acme of the epeiric flooding (Figure 5) Sedimentary accumulation during the Late Cretaceous was characterized by a trend toward enlargement of depositional sites and an increase in the amount of marine influence. At many places, the Upper Cretaceous sequences display progressive overstepping of older terranes (e.g., Mombrú \& Uliana 1979, Zambrano 1980, Bianucci et al. 1982, Biddle et al. 1986). At most locations earlier Mesozoic faults tend to become inactive before the Late Cretaceous (e.g., Zambrano op. cit., Biddle et al. op. cit.) and thickness patterns (Mombrú \& Uliana op. cit., Russo et al.
1980, Zambrano op. cit.) point to a regional style of subsidence, dominated by sediment loading and lithospheric cooling with a minimum of differential downwarping. More pronounced subsidence, presumably related to flexural loading of the South American crust, was only locally developed at back-arc positions within the Magallanes (Biddle et al. op. cit.) and Neuquén basins (Legarreta et al. in press). All along the Atlantic margin the depositional framework was one of prograding wedges, facing a progressively deeper Atlantic ocean. Three segments with different depositional regime can be recognized within this well-established passive margin. Along the Uruguaian and the south-eastern Brazilian portions of the plate edge, subsidence occurred by basement flexure east of a coastal hinge (Gonçalves et al. 1979, Williams \& Hubbard 1984), coupled with isostatic compensation and tectonic uplift west of the hinge (Pereira et al. 1986). The existence of a marginal uplift provided a nearby source of clastics and continued to obstruct the marine encroachment of the Brazilian cratonic interior. The evolution of the Santos basin sedimentary fill records peak flooding and 


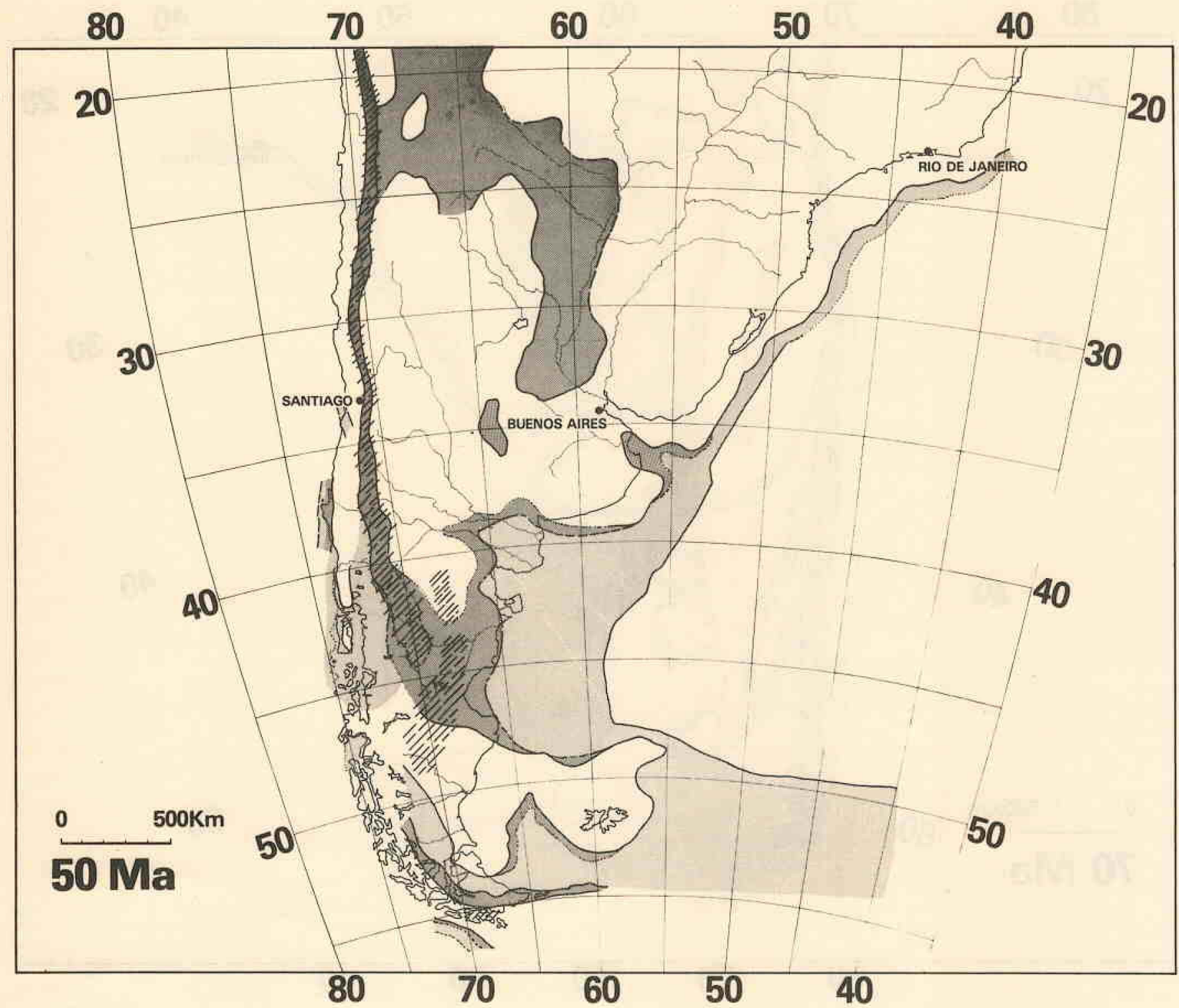

Figure 6-50 Ma (Paleogene) paleogeographic reconstruction showing pause in Andean magmatism and marine retreat. Key as in figure 1

transgressive deposition from late Albian to mid Turonian, followed by accumulation of a progradational wedge during the rest of the Cretaceous period (Pereira et al. 1986). These patterns indicate a considerable effect of global eustatic trends (Haq et al. 1987) on sediment dispersal and accumulation. The regularity of the passive-margin depositional pattern was only locally broken because of slumping and diapiric penetration of older Cretaceous salt (Williams \& Hubbard 1984, Pereira et al. op. cit). South of Uruguay and north of the Malvinas plateau the subsidence regime was different. The outer ridge located inboard of the continental-margin wedge (Rolleri 1972, Urien \& Zambrano 1972) became less and less prominent as a result of subsidence and gentle oceanward tilt of the entire Argentine shelf. Local subsidence rates at the edge of this segment of the South American plate were enough to overcome the global eustatic trends, providing maximum accommodation and drowning of the margin during the latest Late Cretaceous (some $20 \mathrm{Ma}$ after the Turonian peak highstand). The southern continental segment (Malvinas Plateau) continued the submersion trend initiated in the Neocomian. Depositional geometries is area reveal low-angle southerly and easterly directeci progradation, and erosional truncation at the northern edge of the block, presumably associated to regional southward tilting of the Plateau.

The Late Cretaceous flooding of the Argentine margin during a period of tectonic quiescence, when the continental interior was devoid of large topographic barriers, produced a spectacular increase in the size of the areas under marine influence (e.g., Malumián et al. 1983, Salfity et al. 1985). Development of epeiric flooding had started before Maastrichtian time, through limited marine inclursions in Bolivia (Cenomanian, Cherroni 1977) and the Argentine Colorado basin (Turonian?, Lesta et al. 1979). Peak marine influx during the Maastrichtian conceivably occurred across depressed portions of the plate interior, coincident with structural sags developed on top of buried Mesozoic Mesozoic rifts (e.g., Lesta et al. op. cit., Bianucci et al. 1981). Local occurrence of marine accumulations in the fore-arc region of central Chile (Auboín et al. 1973, Davidson 1984) shows that 
the western margin of the plate was also under a submergent regime. Irregularities in the trace of the shoreline have been interpreted as a response to locally differentiated subsidence (Cecioni 1970).

One important side effect of the Late Cretaceous flooding was to reduce the clastic influx into most basins. Shaly and marly facies are thus common, and they locally are associated with carbonates (Moreno 1970, Cherroni 1977, Legarreta et al. s.d.), while areas marginal to the seaways are characterized by red bed-evaporite assemblages (Yrigoyen 1975b, Bracaccini 1980, Russo et al. 1980). Active arc-type magmatism was likely continuous along the entire length of the Pacific margin (e.g., Malumián et al. 1983, Davidson 1984). The conspicuous absence of Maastrichtian marine facies in west-central Patagonia, the general area where the Cretaceous basalts were erupted (Franchi \& Page 1980, Baker et al. 1981), suggests the occurrence of intra-plate doming in the region.

Paleogene plate reorganization: pause in the Andean of the early Tertiary sequences of the Andean domain shows a considerable along-strike variation in depositional regimes. From SW Peru to about $27^{\circ} \mathrm{S}$ in Chile, Paleogene accumulation is represented mostly by a volcanic and volcaniclastic pile devoid of marine members. These deposits record the existence of a magmatic arc with large strato-volcaneos and calderas and minor development of back-arc basins (Audebaud et al. 1973, Coira et al. 1982, Maksaeu 1984). South of $30^{\circ} \mathrm{S}$ the volcanic rocks are associated with lacustrine deposits and were deposited within a series of restricted intermontane basins (Vergara \& Drake 1979, Moscoso 1984, Muñoz 1984, Rivano 1984). A parallel tract of non-volcanic clastics was deposited west of the present Coastal Ranges, in the Navidad, Chanco-Itata, and Arauco depocenters (Cecioni 1980, Mordojovich 1981). These wedges record open-marine influence and contain paralic facies with coal seams, and they seem to have been deposited in narrow intra arc-massif or constructed forearc basins (sensu Seely 1979). South of $39^{\circ}$ S the axis of the volcanic belt swings away from the margin into the North Patagonic Andes and the Somoncura Massif. This turn is connected with a widening of the forearc depocenter (preserved in the Osorno-Puerto Montt and Chiloe basins, Katz 1963a, Valenzuela Ayala 1982), and marine encroachment of the volcanic belt (Ramos 1982). The subsidence required to accommodate these thick Andean pods of volcanics and volcaniclastics $(2,000-3,000 \mathrm{~m})$ is attributed to fault-induced subsidence developed in an extensional crustal regime (Levi \& Aguirre 1981, Muñoz op. cit.). Petrologic work in Argentina also confirms that the volcanic chain represents a calc-alkalic arc related to subduction and coeval with considerable crustal attenuation (Rapela et al. 1983), Rapela et al. 1984).

In a sharp contrast the southernmost Andes shows few indications of magmatic activity (Ramos 1983) and display many of the characteristics of an active margin under regional compression. The Paleogene successions contain thick fandelta wedges fed from a high-relief area to the south, and poured into a fairly deep trough (Natland et al. 1974, Biddle et al. 1986) developed on a downwarped portion of the South American slab. There is clear evidence of uplift and loading subsidence, a combination interpreted as the result of ongoing regional shortening (Katz 1963b, Winslow 1982) and perhaps crustal stacking (Wilson 1983). South of $54^{\circ}$ S early Tertiary dextral strike slip along major faults has'been postulated to account for the existence of some small troughs filled with Paleogene conglomerates and paralic deposits (Caminos et al. 1981).

Sedimentation in mid-plate settings continued to be mostly confined to those basins active during the Late Cretaceous. A considerable reduction in the areal extent of the depositional sites, and the diminution of the regions under marine influence, seems to be the response to base level lowering related to early Tertiary global eustatic fall (Haq et al. 1987). Because of the stable tectonic conditions, intra-plate relief continued to be limited and dominant accumulations are fine grained. In the course of the early Cenozoic, the Maastrichtian seaway that had linked Bolivia and coastal Argentina was transformed in a series of broad aluvial plains and large lake basins (Cazau et al. 1976, Russo et al. 1980, Bianucci et al. 1982). In Patagonia many areas invaded by the Late Cretaceous epeiric flooding turned into vast loess plains made up by distal pyroclastics punctuated with numerous paleosols (Spalletti \& Mazzoni 1977, Franchi et al. 1984, Mazzoni 1985). Late during the Paleogene pyroclastics were associated with extra-Andean emissions of plateau basalts and subvolcanic intrusions with alkalic affinities (Ramos 1983, Coira et al. 1985).

Persistent drowning along the Argentine shelf continued, in contrast with the emergent habit shown by the Uruguay-Brazilian margin. Uplift and normal faulting of the coastal Brazilian basement (Almeida 1976) proceeded along with substantial sediment loading and subsidence in the offshore basins (Asmus 1978, Gonçalves et al. 1979, Pereira et al. 1986). To a large extent, however, pronounced downward shift and offlapping arrangement of the Paleogene clastic wedges (Gonçalves et al. op. cit., Rangel et al. 1986) is attributed to reduction in shelfal accommodation concomitant with global eustatic fall.

The western margin of southern South America was influenced considerably by Eocene plate reorganization (Richardson \& Rona 1980). From about $48 \mathrm{Ma}$ until about 25 $\mathrm{Ma}$ plate reconstructions (Pilger 1983) suggest NE-SW directed convergence along the Pacific edge of the southern South American margin. The change in kinematic regime is parallel in time to important events as the bend of the Hawaiian-Emperor island and seamount chain (Handschumacher 1976), and changes in the interactions between India and Antarctica, and India and Africa (Pilger op. cit.). Local development of compressional deformation within the Andean domain ("Compression fini-éocène" of Audebaud et al. 1973; "Incaic orogenesis" of Coira et al. 1982) could be considered as the local manifestation of this Eocene event. The reorientation in the Nazca-South America convergence vector was closely followed by a sharp decrease in the level of magmatic activity of the Andean arc (Coira et al. 1982), perhaps because the development of a low-angle subduction geometry (Maksaeu 1984, Rapela et al. 1984).

\section{Early Neogene plate reorganization: arc buildup and renewed marine flooding (Figure 7) The $25 \mathrm{Ma}$} modification of the convergence direction between the Nazca plate and the South American slab (Handschumacher 1976, Pilger 1983), which changed from a NE-SW to an essentially E-W orientation, induced important modifications in the Andean arc. Perhaps the most obvious change was reactivation of the main magmatic belt, after a period of relative quiescence that lasted most of the Oligocene (Malvicini \& Llambías 1982). Over large areas igneous activity expanded and invaded the foreland in west-central Argentina, Bolivia and Perú, and by mid Miocene had broadened to locally reach a width of $400 \mathrm{~km}$ (Clark et al. 1976, Malvicini \& Llambías op. cit., McBride et al. 1983). In southern Argentina and Chile, however, the magmatism was superimposed on older arc terranes (Ramos 1983, Malvicini \& Llambías op. cit.), or was located west of the Paleogene volcanic system (Vergara \& Munizaga 1974, Vergara \& López 1982). The early Neogene magmatic expansion ("breakout episode" of Clark et al. op. cit.) has been 


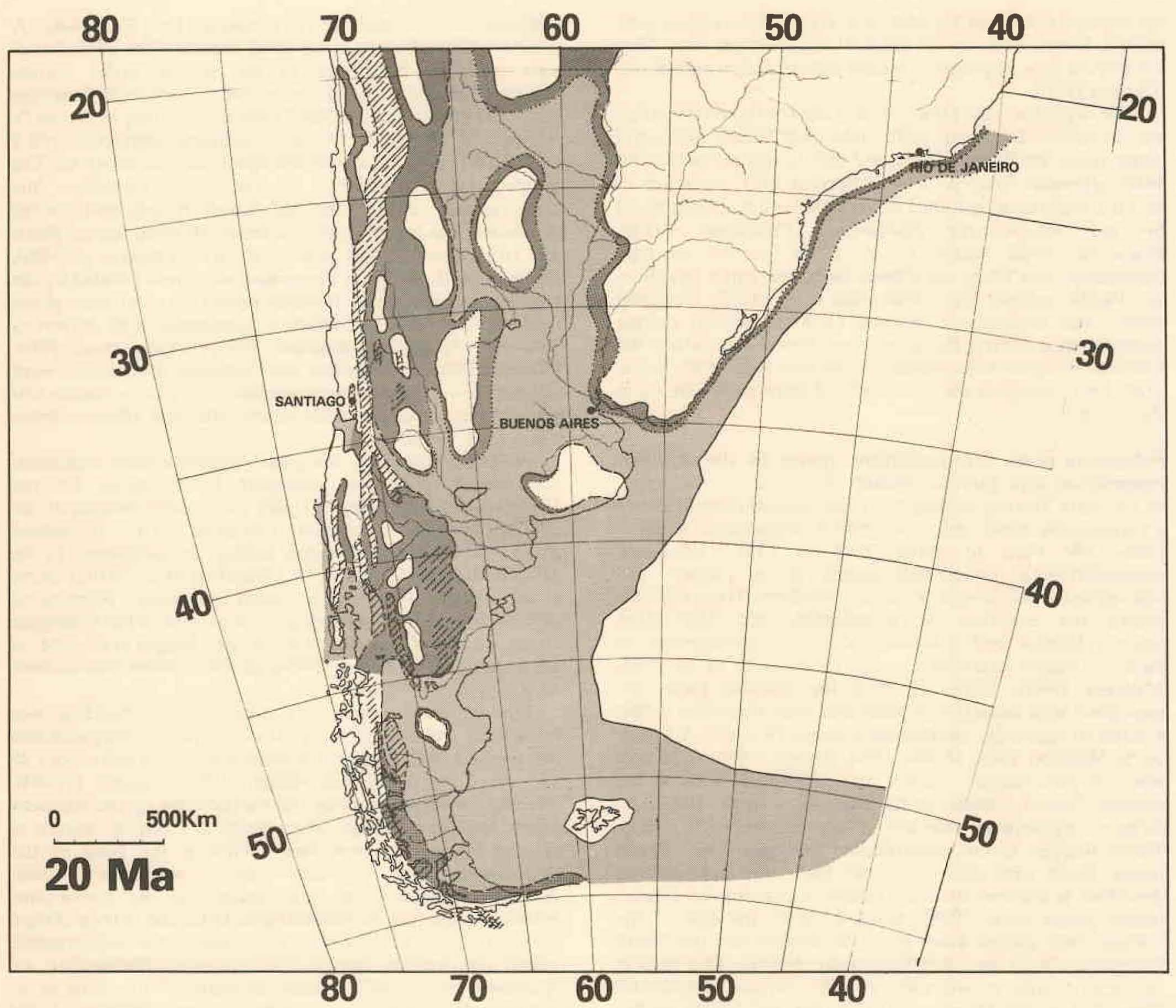

Figure 7-20 Ma (Early Neogene) paleogeographic reconstruction showing arc buildup and renewed marine flooding. Key as in figure 1

interpreted as the response to a down-dip expanse of the zone of melting, prompted by an abrupt increase in the convergence rates along the margin (McBride et al. 1983).

Another important effect of the early Neogene plate reorganization was that the Andean arc became segmented by longitudinal block faulting developed that as a result of extensional tectonics (Katz 1971). During the late Oligocene and early Miocene the present morphological-structural configuration of Chile, Coastal-Range Central-Valley Volcanic Andes, began to develop (Maksaeu 1984, Rivano 1984). Reflection seismic data and drilling in Argentina and Chile at $36^{\circ} \mathrm{S}-42^{\circ} \mathrm{S}$, shows that the entire region from the present fore-arc to the edge of the Patagonia Massif was the site of emplacement of grabens and flexure-bounded basins display internal steps related to NW and NE transverse faulting. Intersection fo the transverse and border faults produced locally irregular basin outlines with doglegs and relay configurations. Recent work (Lavenu \& Marocco 1984) shows the early Neogene Moquegua and Altiplano basins (at the front and core of Perú-Bolivian Andes) as 50-100 km wide, compound half-troughs, framed by synsedimentary faults, and demonstrates the regional magnitude of the early Neogene extensional event. Under these conditions, depositional settings within the arc consisted in longitudinal tectonic depressions filled by non-marine coarse clastics intricately associated with huge piles of proximal volcanics, lacustrine deposits, and marine tongues (González Bonorino \& González Bonorino 1978, Salinas 1981, Franchi et al. 1984).

In the southern Patagonic Andes of Argentina and Chile increase in magmatic activity was modest (Ramos 1983), and although the extrusion of alkalic basalts during the Miocene persisted across the Patagonian foreland (Baker et al. 1981, Corbella 1984, Coira et al. 1985), there is no evidence of pervasive arc or back-arc extensional faulting. Most indicators point to the continuation of flexural downwarping of the Magallanes foredeep trough (Winslow 1982, Wilson 1982, Biddle et al. 1986).

Over many areas of continental Argentina, the upper Paleogene and lower Neogene are missing (e.g., Biddle $e t$ al. 
1986) because a composite regional unconformity largely due to reduced accommodation (erosional beveling plus non-deposition) around the $30 \mathrm{Ma}$ eustatic drop (Haq et al. 1987). On the Atlantic margin this effect has been well documented in the Campos Basin, where the sea-level fall was enough to expose the shelf edge, allowing the incision of several canyons that are associated with extensive lowstand turbidites (Gamboa et al. 1986). The mid Oligocene event of shelf exposure was followed by a change toward increased marine encroachment that lasted from the late Oligocene until the middle Miocene ("Mid Tertiary Transgressive Onlap Sequence" of Williams \& Hubbard 1984), paralleling the early Neogene trend of global eustatic rise (Uliana \& Biddle 1987). Neogene marine inundation occurred in the same general areas as late Cretaceous flooding. Although the map shows the maximum extent of early Neogene marine incursions, the actual span of the marine beds varies from place to because regional onlap on an irregular surface and diachronous comeback of the shoreline as a result of variable rates of clastic influx. Late Oligocene-middle Miocene marine invasion occurred earlier in Patagonia than in eastern and northwestern Argentina, and conversely marine retreat started earlier close to the Andes and in southern Patagonia.

The large areal extent of the Miocene marine deposits reveals that the mean freebord of the plate interior still was consistently low. The same conclusion can be reached considering that the dominant lithofacies are very similar to those developed as a result of the Late Cretaceous drowning. Shales and fine-grained clastics with some carbonates, associated with sabkha evaporites at the fringes of the epeiric seaways, covered eastern and north-western Argentina (Russo \& Serraiotto 1978, Zuzek 1978, Russo et al. 1980). As in the Paleogene, thin pyroclastic loess with paleosols continued to dominate the subaerial settings of Patagonia (Franchi et al. 1984).

Late Neogene changes in the tectonic regime: batholith emplacement, Andean morphogenesis, Cordilleran shortening, and marine withdrawal (Figure 8) Some 15 million years ago, and in many areas 10 million years or even later, the southern South American scene began to be dominated by the processes that led to the present configuration of the Andean tectonic-magmatic belt. The complex sequence of partially overlapping events encompassed: widening of the magmatic arc and emplacement of granitic plutons; regional uplift and Cordilleran morphogenesis; and east-west directed compression and contractional deformation. The Andean uplift in itself promoted overall increase in the magnitude of the sedimentary influx. Because of the augmented topographic relief and late Cenozoic eustatic fall some of those sediments were carried to Atlantic continental margin depocenters. A sizeable proportion, however, was trapped at intra-plate locations to form the sedimentary fill of a new and diverse suite of depositional sites generated as a response to the late Neogene tectonic framework.

Unlike most of the previous Mesozoic-Cenozoic interval, the sedimentary input was largely captured within basins developed under a compressional regime. East of the main Cordilleran belt, 2,000 to $4,000 \mathrm{~m}$ of late Neogene clastics were deposited as asymmetric foreland wedges developed over downflexed portions of the craton in front of segments of the Andean, thin-skinned fold and thrust belt. The Bolivian-Argentine Chaco basin east of the Subandean Ranges (Ahlfeld \& Branisa 1960, Mingramm et al. 1979); the northern portion of the Neuquen basin east of the Principal Cordillera (Yrigoyen 1969, 1979); and the Chilean-Argentine Magallanes basin (Winslow 1982, Biddle et al. 1986) are good examples.

Within the Pampean Ranges salient of the Neogene compressional belt, early Neogene depositional patterns were disrupted by the appearance of several discrete depocenters known as the Bolsones basins that developed as a result of tectonic loading in front of basement-involved uplifts. These basins are large and asymmetric structural depressions (see thickness map in Yrigoyen 1969) framed by basement blocks that are bounded by faults with several kilometers of throw (Caminos 1979, Gordillo \& Lencinas 1979). This Pampean Ranges-Bolsones are behaved as a thick-skinned compressional foreland, where the positive blocks or sierras were uplifted along east- or west-dipping reverse faults with listric profile (González Bonorino 1950, Jordan \& Allmendinger 1986), while the intervening bolsones were partially filled with non-marine clastics.

Other successions of thick late Neogene wedges were deposited over depressed portions of the Andean contractional belt, but still east of the main magmatic arc. These include the Bermejo and Valle de Tulum basins (Ortiz \& Zambrano 1981), formed by concurrent loading by the Precordillera thrust belt to the west and the Valle Fértil-Pie de Palo uplifts to the east; the Santa María Valley basin between the SE margin of the Puna plateau and the Cumbres Calchaquíes block (Russo \& Serraiotto 1978, Bossi \& Palma 1982); and the less well-developed Río Frías-Río Mayo depocenter between the Tepuel-San Bernardo folded belt and the Patagonic Andes (Skarmeta 1976a, González 1978).

Since 10-15 Ma or so the Andes entered a period of batholithic emplacement (Malvicini \& Llambías 1982) and regional uplift (Coira et al. 1982, Uliana \& Biddle 1987). As a result, the opportunity for accumulation of thick sequences within the arc was considerably limited. However, in the Puna-Altiplano region of NW Argentina and Chile from late (middle?) Miocene on, the large early Neogene basins started to split in several depocenters (Méndez 1975, Alonso et al. 1984, Schwab 1985). These depocenters were long and internally drained depressions with playa-lake ponds filled by halite, borax, volcanics, and coarse clastics. These basins evolved while the area was uplifted from close to sea level to their present 2,500-3,500 m altitude. Recent work by Schwab (op. cit.) indicates that subsidence of the troughs was controlled through synsedimentary reverse faulting that produced compressional wedge-grabens (Keilgrabens). Alternatively these basins could reflect supracrustal extension of the Andean orogenic wedge (Platt 1986), required to accommodate shape changes due to underplating by thrust slices.

The presence of the Central valley depression (Rivano 1984) and a series of graben-style fore-arc troughs developed west of the Coastal Range (Mordojovich 1981, Maksaeu 1984) demonstrates that large portions of Chile were dominated by extensional conditions (Katz 1971). The discontinuity of the Central Valley between 28 and $33^{\circ} \mathrm{S}$ since $6 \mathrm{Ma}$ is attributed to segmentation of the Nazca Plate and existence of a flat, subducted slab at that latitude (Cornejo et al. 1984. Rivano 1984). Regional extension and graben formation along the Chilean Central Valley occurred at the same time as shortening in the foreland, both processes being synchronous with the increase of slope at the east and west flanks of the Andes.

The area located east of the front of the contractional belt (Vázques \& Gorroño 1980) remained under relatively stable tectonic conditions (Yrigoyen 1975a). North of Patagonia, the epeiric seaways receded because of general eustatic fall since late middle Miocene and increased sediment imput. Most sags became aggraded and the region was covered by a vast savannah plain (Edad de las Planicies Australes, Pascual \& Bondesio 1982, Pascual 1984), largely under loess-style sedimentation (Teruggi 1957, Pascual et al. 1965).

With the Miocene uplift of the Andes (Skarmeta 1976a) large areas of Patagonia were elevated above the base level and entered into a net erosional regime. Late Neogene deposits are areally restricted and consist of fluvial to eolian 


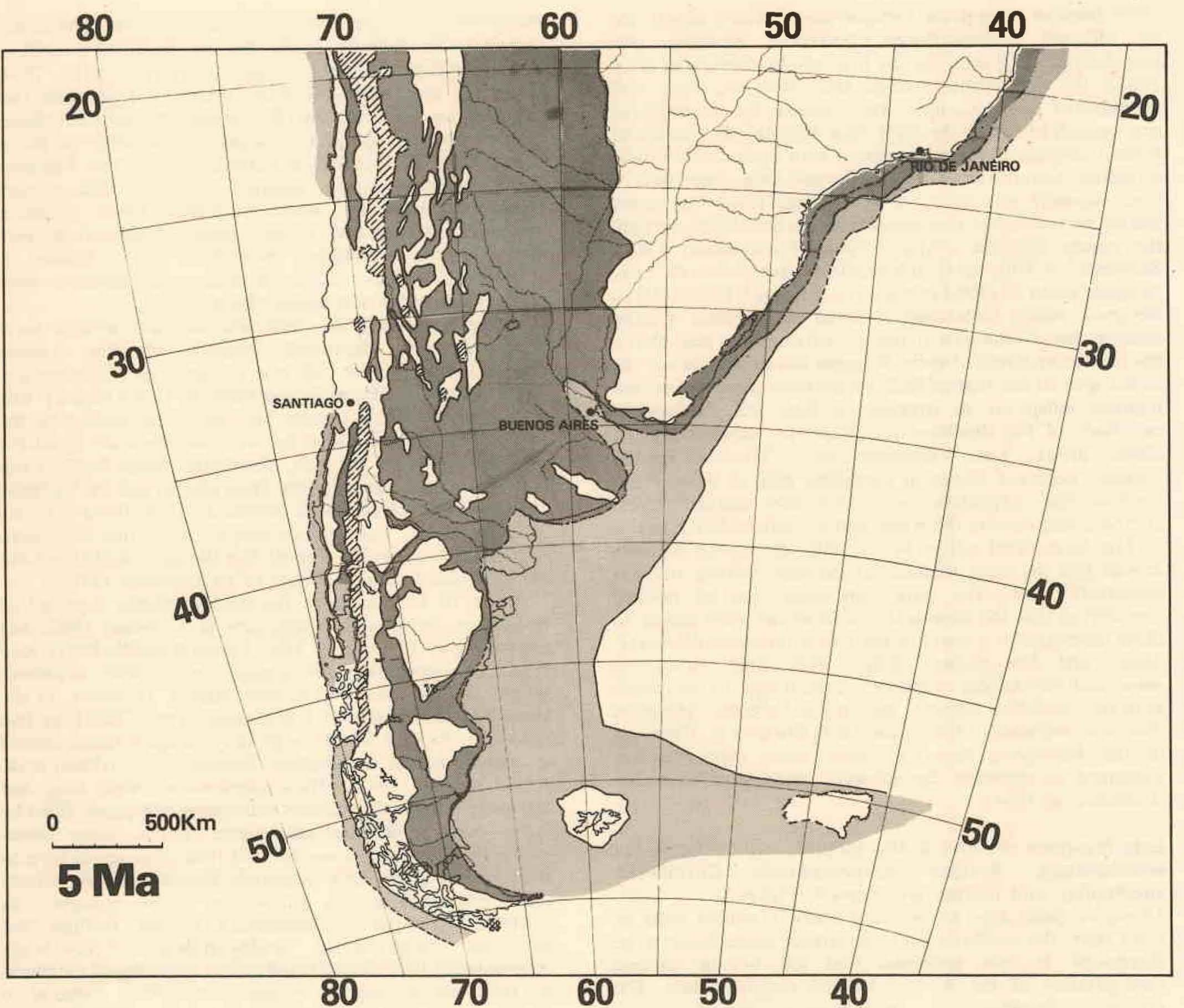

Figure 8 - $5 \mathrm{Ma}$ (Late Neogene) paleogeographic reconstruction illustrating batholith emplacement, Andean Uplift, and marine withdrawal. Key as in figure 1

sandy facies in valley fills related to the fluvial systems that carried Andean debris to the Atlantic shelf (Windhausen 1931, Franchi et al. 1984). The updip edge of the late Neogene marine incursions was confined to positions close to that of the present shoreline. The conditions along the Atlantic shelf can be exemplified with the record of the Santos Basin. Depositional patterns were characterized by basinward displacement of the depocenter, high sedimentation rates, steep depositional slopes, and offlapping disposition of the successive marginal wedges ("Neogene Offlap Sequence", Williams \& Hubbard 1984). Farther away from the Andes, on the Malvinas Plateau, submersion continued to be dominant and sedimentation was essentially biogenic (nannoplankton and siliceous oozes), possibly reflecting vigorous upwelling associated with the mid-Tertiary development of the Circum-Antarctic current. The existence of several truncation surfaces and channeling records the activity of submarine currents, particularly after the late Tertiary opening of the Drake Passage.
Although the time of inception of late Neogene deformation seems to have been variable at different positions of the shortened belt, and precise dating is generally not available, modern studies indicate that pervasive shortening became widespread around $10 \mathrm{Ma}$ when the subducting Nazca plate broke up in segments with different dip (Jordan et al. 1983a). This new situation had considerable effect on the continuity of the arc magmatism. Between $27^{\circ}$ and $33^{\circ} \mathrm{S}$ (the area with a low-angle Benioff zone) magmatic activity waned (Barazangi \& Isacks 1976), and has been quiet for the last 5 million years.

The late Neogene volcanic and volcano-plutonic complexes were developed throughout a wide band that locally extended eastward into the Andean foreland. The Miocene granitic intrusions differ from the larger Cretaceous batholiths; they tend to be mostly smaller bodies and stocks with modest dimensions. The magmatic activity showed was controlled by linear NW-, N-, E-, and NE-oriented structural features (Katz 1971, Gardeweg \& Ramírez 1984), but the 
dominant pattern was one of diffuse activity. This character was also recorded in Perú and attributed to crustal thickening and consequent intrusion of deeply penetrating fractures (Cobbing \& Pitcher 1983). As in the early Neogene, large portions of Patagonia persisted under a different magmatic regime, dominated by extensive basalt flows alkalic affinities (Malvicini \& Llambías 1982). Although the idea of Chilean-type orogenesis, i.e. a mountain belt that develops after subduction of normal oceanic lithosphere beneath a continental margin, is at present a concept with wide acceptance (Cobbing \& Pitcher op. cit., Dalziel 1986) there is less consensus about the mechanisms under which this tectonic process operates. This is particularly so for the late Neogene orogenic complex, a mountain chain with a width and presumably an elevation unmatched in the Mesozoic-Cenozoic history of South America. The present style of deformation is best understood as the result of a complex interplay of several factors associated with the interaction of the Nazca and/or the South American plates (Jordan et al. 1983b). Perhaps the most unique feature of this recent tectonism is the pervasive contractional deformation of large segments of the foreland (Vasquez \& Gorroño 1980).

Control at several locations within the fold belt and in foreland settings (Padula 1972b, Mombrú \& Uliana 1979, Bianucci et al. 1982, Uliana \& Biddle 1987) shows that shortening in many areas proceeded along former extensional ruptures developed during the Mesozoic or Cenozoic extensional events. Increase in the horizontal component of compressive stress related to underthrusting (Lowell 1985) seems responsible for the development of inversion structures ("Sunda"-folds) and at least part of the late Cenozoic crustal thickening. The reason behind the occurrence of compressional deformation $500-700 \mathrm{~km}$ east of the trench remains obscure (on the subject see Jordan \& Allmendinger 1986), but perhaps should be looked for in reduction of the crustal strength and delamination (Bally 1984) promoted by the conditions responsible for the voluminous early-mid Neogene magmatism.

FINAL REMARKS Synthesis of the available data at the scale of the maps presented in this paper provides of the geodynamic evolution of Southern South America that is in general agreement with the continental-scale plate reconstructions based on sea-floor magnetic information.

Most of the large-scale tectonic, magmatic, and depositional events that occurred since the early Mesozoic can be reasonably well explained by the interaction of the Pacific, Nazca, South American, and African plates.

Several important questions remain to be addressed. Among these are: 1. what controlled the contrasting subsidence patterns displayed by different segments of the Atlantic margin; 2. why do segments of the active, subducting margin have a limited (or no) accretionary wedge; 3 . what led the inception and maintenance of extensional conditions across the leading edge of the South America plate; 4. what controlled the timing and location of the midplate magmatic events; and 5. what regulated the extreme width of the late Neogene tectonic-magmatic belt. The answers to these questions are no doubt complex and multiple.

From a paleogeographic perspective, we note that the history of land-sea distribution over the southern South American slab matches fairly well with what would be expected from proposed eustatic trends, if local tectonic overprinting, average continental freeboard, and sediment imput are considered. The major discrepancies can be reasonably well explained in terms of regional tectonic events that overrided the eustatic signal and/or because the presence of topographic barriers that hampered marine encroachment.

Acknowledgements This contribution stems from long-term study of southern South American stratigraphy and paleogeography by the senior author, and from collaborative studies beginning in the early 1980's to evaluate the petroleum potencial of Argentine basins. A.C. Riccardi of La Plata University and Conicet provided literature and advice. V.A. Ramos of Servicio Geológico Nacional and Buenos Aires University supplied important references, revised an early draft of the maps, and reviewed the manuscript. We thank Exxon Productin Research Company for permission to publish this work.

\section{REFERENCES}

ABERG, G.; AGUIRRE, L.; LEVI, B.; NYSTROM, J.O. - 1984 Spreading, subsidence and generation of ensialic marginal basins: an example from the Early Cretaceous of Central Chile. In: VOKELAAR, B.P. \& M HOWELLS M.F. eds. Marginal basin geology. Geol. Soc. of London (Spec. Publ. 16) 185-193.

AGUIRRE URRETA, M.B. \& RAMOS, V.A. - 1981 - Estratigrafía y Paleontología de la alta cuenca del Río Roble, Cordillera Patagónica, Provincia de Santa Cruz. In: CONG. GEOL. ARGENTINO 8, 1981. Actas... Buenos Aires. v. 3, p. 101-138.

AHLFELD, F. \& BRANISA, L. - 1960 - Geologla de Bolivia. Inst. Boliviano del Petróleo, La Paz. Ed. Don Bosco. 245 p.

ALMEIDA, F.F.M.' de - 1967 - Origem e evolução da plataforma brasileira. DNPM/DGM. Rid de Janeiro. $36 \mathrm{p}$. (Bol. 241).

ALMEIDA, F.F.M. de - 1976 - The system of continental rifts bordering the Santos Basin, Brazil In: SIMP. INTER. SOBRE AS MARGENS CONTINENTAIS DO TIPO ATLÂNCICO. $A n$. Acad. bras. Cienc., 48(Supl.): 15-26.

ALONSO, R.N.; VIRAMONTE, J.; GUTIERREZ, R. - 1984 - Puna Austral. Bases para el subprovincialismo geológico de la Puna Argentina. In: CONG. GEOL. ARGENTINO, 9, Buenos Aires, 1984. Actas... Buenos Aires. v. 1, p. 43-63.

ASMUS, H.E. - 1975 - Controle estructural da deposição mesoz6́ica nas bacias da margem continental Brasileira. Rev. Bras. Geoc. 5(3): $160-175$

ASMUS, H.E. - 1978 - Hipóteses sobre a origem dos sistemas de zonas de fraturas oceânicas/alinhamentos continentais que ocorrem nas regiōes sudeste e sul do Brasil. Petrobrás, Rio de Janeiro, p. 39-73. (Série Projeto Remac 4).

ASMUS, H.E - 1981 - Geologia das bacias marginais atlânticas Mesozóicas-Cenozóicas do Brasil. In: Cuencas sedimentarias del Jurásico y Cretácico de América del Sur. Comité Sudamericano del Jurásico y Cretácico, v. I, 127-155, Buenos Aires.
ASMUS, H.E. \& BAISCH, P.R. - 1983 - Geological evolution of the Brazilian continental margin. Episodes, (4):3-9.

ASMUS, H.E \& CARVALHO, V.C. - 1978 - Condicionamento tectônico da sedimentação nas bacias marginais do Nordeste do Brasil (Sergipe/Alagoas e Pernambuco/Paraß́ba) In: PETROBRÁS. Aspectos estruturais da margem continental leste e sudeste do Brasil. Rio de Janeiro. (Série Projeto Remac 4) p. 7-24.

ASMUS, H.E. \& GUAZELLI, W. - 1981 - Sumário das estruturas da margem continental brasileira e das áreas continentais e oceânicas adjacentes, hipóteses sobre o tectonismo causador, e implicaçóes no prognóstico de seu potencial em recursos minerais. Petrobrás, Rio de Janeiro, p. 187-269. (Série Projeto Remac 9).

ASMUS, H.E \& PORTO, R - 1980 - Diferencas nos estágios iniciais da evolução da margem continental brasileira: possíveis causas e implicaçōes. In: CONGR. BRAS. GEOL. 31, Baln. Camboriú, 1980. Anais... Baln. Camboriú, SBG. v. 1, p. 225-239.

AUBOIN, J.; BORRELLO, A.V.; CECIONI, G.; CHARRIER, R. CHOTIN, P.; FRUTOS, J.; THIELE, R.; VICENTE, J.C. - 1973 - Esquisse paléogéographique et structurale des Andes Méridionales. Rev. Géograph. Phys. et Géol. Dyn., XV(1-2):11-72. Paris.

AUDEBAUD, E.; CAPDEVILA, R.; DALMAYRAC, B.; DEBELMAS, J.; LAUBACHER, G.; LEFEVRE, C.; MAROCCO, R.; MARTINEZ, C.; MATTAUER, M.; MEGARD, F.; PAREDES, J.; TOMASI, P. - 1973 - Les traits geologiques essentiels des Andes Centrales (Pérou-Bolivie). Rev. de Géogr. Phys. et Géol. Dyn., XV(1-2):73-114. Paris.

AVILA-SALINAS, W.A. - 1986 - Magmatismo cretácico en Bolivia. In: Cretácico de América Latina. Primer Simposio, p. 52-70. La Paz. (PIGC-Proyecto 242).

BALLY, A.W. - 1984 - Tectonogenése et sismique réflexion. Bull. Soc. Géol. France, (7) XXVI, n² 2, 279-285. 
BAKER, P.E.; REA, W.J.; SKARMETA, J.; CAMINOS, R.; REX, D.C. - 1981 - Igneous history of the Andean Cordillera and Patagonian Plateau around latitude $46^{\circ}$ S. Phil. Trans. Roy. Soc. of London, A.303:105-149.

BARAZANGI, M. \& ISACKS, B.L. - 1976 - Spatial distribution of earthquakes and subduction of the Nazca Plate beneath South America. Geology, 4:686-692.

BARKER, P.F.; DALZIEL, I.W.D. and others - 1976 - Initial reports of the Deep Sea Drilling Project. v. 36, Washington, U.S. Government Printing Office, $1080 \mathrm{p}$.

BELLIENI, G.; BROTZU, P.; COMIN-CHIARAMONTI, P.; ERNESTO, M.; MELFI, A.; PACCA, I.G.; PICCIRILLO, E.M. 1984 - Flood basalt to rhyolite suites in the Southern Paraná Plateau (Brazil): Paleomagnetism, petrogenesis and geodynamic implications. J. Petrol., 25, part 3: 579-618.

BIANCHI, J.L. - 1986a - Areas en licitación Cuenca Golfo San Jorge. In: Petróleo y gas en Argentina. Centro Internacional de Información Empresaria, v. 1, p. 223-237. Buenos Aires.

BIANCHI, J.L. - 1986b - Areas de licitación cuencas costa afuera, In: Petróleo y gas en Argentina. Centro Internacional de Información Empresaria, v. 1, p. 239-272. Buenos Aires.

BIANUCCI, H.A. \& HOMOVC, J.F. - 1982 - Tectogénesis de un sector de la cuenca del subgrupo Pirgua, Noroeste Argentino. In: CONG. LATINOAM. DE GEOL., 5, Buenos Aires. 1982. Actas...

BIANUCCI, H.; ACEVEDŌ, O.; CERDAN, J. - 1981 - Evolución tectosedimentaria del Grupo Salta en la subcuenca Lomas de Olmedo (Províncias de Salta y Formosa). In: CONG. GEOL. ARGENTINO, 8, Buenos Aires. 1981. Actas... Buenos Aires. v. 3, p. $159-172$

BIANUCCI, H; HOMOVC, J.F; ACEVEDO, O.M. - 1982 Inversión tectónica y plegamientos en la Comarca Puesto Guardián- Dos Puntitos. Dpto. Orán, Provincia de Salta. In: CONG. LATINOAM. DE GEOL., 5, Buenos Aires, 1982. Actas... Buenos Aires. p. 23-30.

BIDDLE, K.T.; ULIANA, M.A.; MITCHUM, R.M., Jr.; FITZGERALD, M.G.; WRIGHT, R.C. - 1986 - The stratigraphic and structural evolution of the central and eastern Magallanes Basin, southern South America. In: ALLEN, P.A. \& HOMEWOOD, P. eds. Foreland basins: Spec. Internat. Assoc. of Sedimentol., p. 41-61. Blackwell. (Publication 8).

BOSSI, G.E. \& PALMA, R.M. - 1982 - Reconsideración de la estratigrafía del Valle de Santa María, Provincia de Catamarca, Argentina. In: CONG. LATINOAM. DE GEOL., 5, Buenos Aires, 1982. Actas... Buenos Aires. v. 1, 155-172.

BRACACCINI, O.I. - 1980 - Cuenca deI Salado. In: TURNER, J.C.M. coord. Segundo Simposio de Geologia Regional Argentina. Acad. $\mathrm{Nac}$. de Cienc. de Córdoba, II:879-918, Córdoba.

BRICE, S.E.; COCHRAN, M.D.; PARDO, G.; EDWARDS, A.D. 1982 - Tectonics and sedimentation of the South Atlantic rift sequence: Cabinda, Angola, In: WATKINS, J.S. \& DRAKE, C.L. eds. Studies in continental margin geology. Amer. Assoc. Petrol. Geol. p. 5-18 (Memoir 34).

BRISTOW, J.W. \& SAGGERSON, E.P. - 1983 - A general account of Karroo vulcanicity in southern Africa. Geol. Runds, 72:1015-1060

BRUHN, R.L.; STERN, C.R.; DE WITT, J.J. - 1978 - Field and geochemical data bearing on the development of a Mesozoic volcano-tectonic rift zone and back-arc basin in southernmost South America. Earth and Plan. Sci. Lett., 41:32-46.

BURKE, K.C. \& WHITEMAN, A.J. - 1973 - Uplift, rifting and the breakup of Africa. In: TARLING, D.H. \& RUNKORN, S.K. eds. Implications of continental drift to the earth sciences. Academic Press, v. 2, p. 735-755.

CAMINOS, R. - 1979 - Sierras Pampeanas Noroccidentales. Salta, Tucumán, Catamarca, La Rioja y San Juan. In: TURNER, J.C.M., coord. Segundo Simposio de Geología Regional Argentina. Acad. Nac. de Cienc. de Córdoba, 1:225-291, Córdoba.

CAMINOS, R.; HALLER, M.J.; LAPIDO, O.; LIZUAIN, A.; PAGE, R.N.; RAMOS, V.A. - 1981 - Reconocimiento geológico de los Andes Fueguinos, Territorio Nacional de Tierra del Fuego. In: CONG. GEOL. ARGENTINO, 8, Buenos Aires. Actas... Buenos Aires. v. 3, p. 759-786.

CAZAU, L.B.; CELLINI, N.; OLIVER GASCON, J, - 1976 - El Subgrupo Santa Bárbara (Grupo Salta) en la porción oriental de las provincias de Salta y Jujuy. In: CONG. GEOL. ARGENTINO, 6, Buenos Aires, 1976. Actas... Buenos Aires. v. 1, p. 341-356.

CECIONI, E. - 1970 - Esquema de paleogeografia chinela. Santiago, Editorial Universitaria de Chile, $143 \mathrm{p}$.

CECIONI, G. - 1980 - Darwin's Navidad Embayment, Santiago region, Chile, as a model of the southeastern Pacific shelf. $J$. Petrol. Geol., 2(3):309-321.

CECIONI, G. \& WESTERMANN, G. - 1968 - The Triassic-Jurassic marine transition of coastal central Chile. Pacific Geology, 1:41-75.

CHARRIER, R. - 1979 - El Triásico en Chile y regiones adyacentes de Argentina: una reconstrucción paleogeográfica y paleoclimática. Univ. de Chile, Fac. de Cienc. Fis. y Mat. Depart. de Geol., San- tjago, p. 1-137. (Comunicaciones 26).

CHARRIER, R. - 1984 - Areas subsidentes en el borde occidental de la cuenca de tras-Arco jurássico-cretácica, Cordillera Principal Chilena entre $34^{\circ}$ y $34^{\circ} 30^{\prime} \mathrm{S}$. Noveno. In: CONGR. GEOL. ARGENTINO, 9, Buenos Aires, 1984. Actas... Buenos Aires, v. 2, p. $107-124$.

CHARRIER, R. \& COVACEVICH, V. - 1980 - Paleogeografía y bioestratigrafía del Jurásico Superior y Neocomiao en el sector Austral de los Andes Meridionales Chilenos ( $42^{\circ}-56^{\circ}$ latitud sur). In: CONG. ARGENTINO DE PALEONT. Y BIOESTRAT., 2, Buenos Aires, 1980. Actas... Buenos Aires. v. 5, p. 153-174.

CHERRONI MENDIETA, C, - 1977 - El sistema Cretácico en la parte boliviana de la Cuenca Cretácica Andina. La Paz. Yacim. Petrol. Fisc. Bolivianos, Revista técnica, VI(1):5-46.

CHONG, G. \& HILLEBRANDT, A. - 1985 - El Triásico preandino de Chile entre los $23^{\circ} 30^{\prime}$ y $26^{\circ} 00^{\prime}$ de lat. sur. In: CONGR. GEOL. CHILENO, 4, Antofagasta. Actas... Antofagasta. v. 1, p. 1-162 $1-209$.

CIESIELSKI, P.F. \& WISE, S.H., Jr. -1977 - Geologic history of the Maurice Ewing Bank of the Falkland Plateau (Southwest Atlantic sector of the Southern Ocean) based on piston and drill cores. Mar. Geol. (25):175-207.

CISTERNAS, M.E. - 1979 - Litofacies de transición marino-continental en el Jurássico del sector La Ola, al sur del Salar de Pedernales. In: CONG. GEOL. CHILENO, 2, Arica. Actas... Arica. v. 1, p. A65-A85.

CISTERNAS, M.E. \& VICENTE, J.C. - 1976-Estudio geológico del sector de Las Vegas de San Andrés (Prov. de Atacama, Chile). In: CONGR. GEOL. CHILENO, 1, Santiago, 1976. Actas... Santiago. v. 1, p. A227-A252.

CLARK, A.H.; FARRER, E.; CAELLES, J.C.; HAYNES, S.J.; LORTIE, R.B.; MCBRIDE, S.L.; QUIRT, G.S.; ROBERTSON, R.C.R.; ZENTILLI, M. - 1976 - Longitudinal variations in the metallogenetic evolution of the Central Andes: a progress report. In: STRONG, D.F. ed. Metallogenesis and plate tectonics. Geol. Assoc. Canada, p. 23-58. (Special Paper 14).

COBBING, E.J. \& PITCHER, W.S. - 1983 -Andean plutonism in Peru and its relationship to volcanism and metallogenesis at a segmented plate edge. Geol. Soc. of Amer., p. 277-291. (Memoir 159).

COIRA, B.L.; DAVIDSON, J.D.; MPODOZIZ, C.; RAMOS, V.A. 1982 - Tectonic and magmatic evolution of the Andes of Northern Argentina and Chile. Earth Sci. Rev., 18(3-4):303-332.

COIRA, BL.; FRANCHI, M.; NULLO, F.E. - 1985 - Vulcanismo terciário al oeste de Somuncura y relación con el arco magmático de la Cordillera Nordpatagónica, Argentina. In: CONGR. GEOL. CHILENO, 4, Antofagasta, 1985. Actas... Antofagasta. v. 4, p. 468-488.

CORBELLA, H. - 1984 - El vulcanismo de la Altiplanicie del Somuncura. In: CONGR. GEOL. ARGENTINO, 9, Buenos Aires, 1984. Relatório 1... Buenos Aires. v. 10, p. 267-300.

CORNEJO, P.; MPODOZIS, C.; NASI, C. - 1984 - Geología y alteración hidrotermal de la alta Cordillera entre Copiapó y Ovalle. In: Seminario Actualización de la Geología de Chile, Apuntes. Serv. Nac. de Geol. y Min., Santiago, 1984. Miscelánea 4:H $1-\mathrm{H} 45$.

CORTES, J.M. - 1981 - El substrato precretácico del extremo noroeste de la Provincia del Chubut. Asoc. Geol. Arg., Revista, XXXIV(3):217-235, Buenos Aires.

CORTIN̂AS, J.S. - 1984 - Estratigrafía y facies del Jurásico entre Nueva Lubecka, Ferrarotti y Cerro Colorado, su relación con los depósitos coetáneos del Chubut central. In: CONGR. GEOL. ARGENTINO, 9, Buenos Aires, 1984. Actas... Buenos Aires. v. 2, p. 283-299.

CORTIÑAS, J.S. \& ARBE, H.A. - 1981 - EI Cretácico continental de la región comprendida entre los cerros Guadal y Ferrarotti, Departamento Tehuelches, Provincia del Chubut. In: CONGR. GEOL. ARGENTINO, 8, Buenos Aires, 1981. Actas... Buenos Aires. v. 3, p. 359-372.

CRIADO, P. - 1979 - Subcuenca de Alvear (Provincia de Mendoza). In: TURNER, J.C.M. coord. Geologia regional argentina. Córdoba. Acad. Nac. de Cienc. de Córdoba, I:811-835.

CRIADO, P.; MOMBRU, C.A.; RAMOS, V.A. - 1981 - Estructura e interpretacion tectónica. In: CONGR. GEOL. ARGENTINO, 8, Buenos Aires, 1981. Relatório... Buenos Aires, p. 155-192. Geología y recursos naturales de la Provincia de San Luis.

DALZIEL, I.W.D. - 1981 - Back-arc extension in the Southern Andes: a review and critical reappraisal. Phil. Trans. Royal Soc. London, A300:319-335.

DALZIEL, I.W.D. - 1986 - Collision and Cordilleran orogénesis: an Andean perspective. In: COWARD, M.V.\& RIES, A.C. Collision tectonics. p. 389-404. (Geol. Soc. Spec. Publ. 19).

DALZIEL, I.W.D.; de WIT, M.J.; PALMER, K.F. - 1974 - Fossil marginal basin in the Southern Andes. Nature, 250:291-294.

DAVIDSON, J. - 1984 - Introduccíon a la Geología de Chile. In: Seminario actualización de la Geologia de Chile, Apuntes. Serv. Nac. de Geol. y Min., Santiago, Miscelánea 4:B 1-B24.

DAVIDSON, J. \& GODOY, E. - 1976-Observaciones sobre un perfil geológico de los Andes Chilenos en la latitud $25^{\circ} 40^{\prime} \mathrm{S}$. In: CONG. 
GEOL. ARGENTINO, 6, Buenos Aires, 1976. Actas... Buenos Aires. v. 1, p. 69-87.

DE CASTRO, J.C.; DE AZAMBUJA FILHO, N.C. \& XAVIER, A.A. - 1981 - Fácies e análise estratigráfica da Formacấo Lagoa Feia, Cretácico Inferior da Bacia de Campos, Brasil. In: CONGR. GEOL. ARGENTINO, 8, Buenos Aires, 1981. Actas... Buenos Aires. v. 2, p. 567-576.

DE GUISTO, J.M.; DI PERSIA, C.A.; PEZZI, E. -1980-Nesocratón del Deseado. In: TURNER, J.C.M. coord. Segundo Simposio de Geologfa Regional Argentina. Córdoba, Acad. Nac. de Cienc. de Córdoba, II: $1389-1430$.

DEGRAFF, J.M. - 1985 - Late Mesozoic crustal extension and rifting on the western edge of the Paraná Basin, Paraguay. Geol. Soc. Amer., Abstracts with Programs, v. 17, n.7, p. 560 .

DIAS-BRITO, D. - 1982 - Evolução paleoecológica da Bacia de Campos durante a deposiçāo dos calcilutitos, margas e folhelhos da Formaçāo Macaé (Albiano e Cenomaniano?). Rio de Janeiro. Bol. Téc. Petrobrás, 25(2):84-97.

DIGREGORIO, J.H. \& ULIANA, M.A. - 1980 - Cuenca Neuquina. In: TURNER, J.C.M. coord. Segundo Simposio de Geologia Regional Argentina. Córdoba. Acad. Nac. de Cienc. de Córdoba, tomo II: 985-1032.

DINGLE, R.V.; SIESSER, W.G.; NEWTON, A.R. - 1983-Mesozoic and Tertiary Geology of Southern Africa. A.A. Balkema, 375 p. Rotterdam.

ESPINOZA REYES, S.T. - 1986 - El legado metalogenético de la cuenca del Neocomiano entre los paralelos $26^{\circ}$ y $31^{\circ}$ de latitud sur en los Andes Centrales. In: CRETÁCICO DE AMÉRICA LATINA. Primer Simposio, PICG, La Paz, p. 87-107. (Proyecto 242).

FERUGLIO, E. - 1949-1950 - Descripción geologica de la Patagonia. Buenos Aires, Yacimientos Petrolíferos Fiscales, I (1949): 1-349; III (1950): 1-431.

FLETCHER, C.J.N. \& LITHERLAND, M. - 1981 - The geology and tectonic setting of the Velasco alkaline province, eastern Bolivia. $J$. Geol. Soc., 138(5):541-548.

FODOR, R.V.; MCKEE, E.H.; ASMUS, H.E. - 1983-K-Ar ages and the opening of the South Atlantic Ocean: Basaltic rock from the Brazilian margin. Mar. Geol., 54:M1-M8.

FRANCHETEAU, J. \& LE PICHON, X. - 1972 - Marginal fracture zones as structural framework of continental margins in South Atlantic Ocean. Am. Assoc. Petrol. Geol. Bull., 56(6):991-1007.

FRANCHI, M.R. \& PAGE, R.F.N. - 1980 - Los basaltos Cretácicos y la evolución magmática del Chubut occidental. Buenos Aires, Asoc. Geol. Argentina, Revista, XXXV:208-229.

FRANCHI, M.R.; NULLO, F.E.; SEPULVEDA, E.G.; ULIANA, M.A. - 1984 - Las sedimentitas terciarias. In: CONG. GEOL. ARGENTINO, 9, Buenos Aires, 1984. Relatório... Buenos Aires. v. 1(9), p. 215-266.

FRUTOS, J. - 1981 - Andean tectonics as a consequence of sea-floor spreading. Tectonophysics, 72:T21-T32.

GAMBOA, L.A.P.; ESTEVES, F.R.; SHIMABUKUEO, S.; PERES, W.E.; SOUZA CRUZ, C.E. - 1986 - Evidências de variaçōes de nível do mar durante o Oligoceno e suas implicaçöes faciológicas. In: CONGR. BRASIL. GEOL., 34, Goiânia, 1986. Anais... Goiânia, SBG. v.1, p. 8-22.

GARDEWEG, M. \& RAMIREZ, C.F. - 1984 - Volcanismo del Cenozoico superior del altiplano Chileno (183-283 L.S.). In: Seminario Actualización de la Geologia de Chile. Apuntes. Serv. Nac. de Geol. y Min., Santiago. Miscelánea. 4:E1-E31.

GERRARD, I. \& SMITH, G.C. - 1982 -Post-Paleozoic succession and structure of the southwestern African Continental margin. In: Studies in continental margin geology. Tulsa, Am. Assoc. Petr. Geol. p. 49-74. (Memoir 34).

GONCALVES, A.; OLIVEIRA, M.A.M.; MOTTA, S.O. - 1979 Geologia da Bacia de Pelotas e da Plataforma de Florianópolis. Bol. Téc. de Petrobrás, 22(3):157-174.

GONZÁLEZ, R.R. - 1971 - Edades radimétricas en algunos cuerpos eruptivos de Argentina. Asoc. Geol. Argentina, Revista, 26(3):411-412.

GONZÁLEZ, R.R.L. - 1978 - Descripción geológica de las hojas 49a, Lago Blanco y 49b, Paso Rio Mayo. Buenos Aires, Serv. Geol. Nac. Bol. 154-155, 45 p.

GONZÁLEZ,BONORINO, F. - 1950-Algunos problemas geológicos de las sierras Pampeanas. Buenos Aires. Asoc. Geol. Arg. Revista, 5(3):81-110.

GONZÁLEZ BONORINO, F. \& GONZÁLEZ BONORINO, F. - 1978 - Geología de la región de San Carlos de Bariloche: Un estudio de las formaciones terciarias del Grupo Nahuel Huapi. Buenos Aires, Asoc. Geol. Argentina, Revista, XXXIII(3): 175-210.

GORDILLO, C.E. \& LENCINAS, A.N. - 1979-Sierras Pampeanas de Córdoba y San Luis. In: TURNER, J.C.M. coord. Segundo Simposio de Geología Regional Argentina. Córdoba, Acad. Nac. de Cienc. de Córdoba (I):577-650.

GROEBER, P.F.C. - 1953 - Mesozoico. In: STIPANICIC, P.N. \& MINGRAMM col. Geografta de la República Argentina. Tomo II, primera parte. Buenos Aires, Imprenta Coni, 541 p.

GUST, D.A.; BIDDLE, K.T.; PHELPS, D.W.; ULIANA, M.A. -
1985 - Associated Middle to Late Jurassic volcanism and extension in Southern South America. Tectonophysics, 116:223-253.

GWINNER, M.P. - 1978 - Geologie der Alpen. Stuttgart, West Germany, E. Schweozerbart'sche Verlagsbuchhandlung, $480 \mathrm{p}$.

HALLER, M.J. - 1985 - El magmatismo mesozoico en Trevelin, Cordillera Patagónica. In: CONG. GEOL. CHILENO, 4, Antofagasta, 1985. Actas... Antofagasta. v. 4, p. 4-215 - 4-234.

HALLER, M.J. \& LAPIDO, O. - 1980 -EI Mesozoico de la Cordillera Patagónica central. Buenos Aires. Asoc. Geol. Argentina, Revista, XXXV(2):230-247.

HALLER, M.J. \& LAPIDO, O.R. - 1982 - The Jurassic-Cretaceous volcanism in the Septentrional Patagonian Andes. Earth Sci. Rev., 18:395-410.

HALLER, M.J.; LIZUAIN, A.; PAGE, R.F.N. - 1981 - El mar Tithono-Neocomiano en la evolución de la Cordillera Norpatagónica. In: Cuencas Sedimentarias del Jurásico y Cretácico de América del Sur. Buenos Aires. Comité Sudamericano del Jurásico y Cretácico, v. 1. p. 221-237.

HANDSCHUMACHER, D.W. - 1976 - Post Eocene plate tectonics of the Eastern Pacific. Am. Geophys. Union Mem., 19:177-202.

HAQ, B.U.; HARDENBOL, J.; VAIL, P.R. - 1987 - Chronology of fluctuating sea levels since the Triassic ( 250 million years ago to present). Science, 235:1156-1167.

HARRINGTON, H.J. - 1962 - Paleogeographic development of South America. Am. Assoc. Petrol. Geol. Bull., 46(10):1773-1814.

HERVE, M.; SUAREZ, M.; PUIG, A. - 1984 - The Patagonian Batholith south of Tierra del Fuego, Chile: Timing and Tectonic implications. Geol. Soc. London, 141:909-917.

JENSEN, O. - 1976 - Geología de las nacientes del rio Copiapo, entre los $27^{\circ} 53^{\prime}$ y $28^{\circ} 20^{\prime}$ de latitud sur, Provincia de Atacama, Chile. Memoria de prueba, Depto. Geología, Fac. Cienc. Fis. y Mat. Universidad de Chile. 249p.

JENSEN, O. - 1976 - Geología de las nacientes del río Copiap6, entre los $27^{\circ} 53^{\prime}$ y $28^{\circ} 20^{\prime}$ de latitud sur, Provincia de Atacama, Chile, Memória de Prueba, Depto. Geología, Fac. Cienc. Fis. y Mat., Universidad de Chile, $249 \mathrm{p}$.

JORDAN, T.E. \& ALLMENDINGER, R.W. - 1986 - The sierras Pampeanas of Argentina: a modern analogue of Rocky Mountain foreland deformation. Am. J. Sci. 286:737-764.

JORDAN, T.E.; ISACKS, B.L.; RAMOS, V.A.; ALLMENDINGER, R.W. - 1983a - Mountain building in the Central Andes. Episodes, 1983(3):20-26.

JORDAN, T.E.; ALLMENDINGER, R.W.; BREWER, J.A.; RAMOS, V.A.; ANDO, C.J. - 1983b - Andean tectonics related to geometry of subducted Nazca plate. Geol. Soc. Am. Bull., 94:341-361.

JORDI, H.A. \& LEHNER, P. - 1973 - Regional seismic profiles across the Atlantic margin of South America and South Africa. In: CONG. BRAS. GEOL. 27, Aracaju, 1973. Anais... Aracaju, SBG. v. 3, p. $67-90$.

KATZ, H.R. - 1963a - Erdol geologische untersuchungen in Chilenischen langstal. Erdol und Kohle erd gas. Petrochemie, 16, Nov., 1963:1089-1094.

KATZ, H.R. - 1963b - Revision of Cretaceous stratigraphy in Patagonian Cordillera of Ultima Esperanza, Magallanes Province, Chile. Am. Assoc. Petrol. Geol. Bull., 47:506-524.

KATZ, A.R. - 1971 - Continental margin in Chile - is tectonic style compressional or extensional? Am. Assoc. Petrol. Geol. Bull., 55 (10): $1753-1768$

LARSON, R.L. \& PITMAN, W.C. - 1972 - World-wide correlation of Mesozoic magnetic anomalies, and its implications. Geol. Soc. Am. Bull., 83 (12):3645-3661.

LAVENU, A. \& MAROCCO, R. - 1984 - Sedimentation continentale et tectonique d'une chaîne liée zone de subduction, l'exemple des Andes Centrales (Pérou-Bolivie) pendant le Tertiaire. In: $L a$ Sedimentation Continentale. Pau. Cent. Rech. Explor.-Prod. Elf-Aquitaine. Bulletin, 8 (1):57-70.

LE BAS, M.J. - 1971 - Per-Alkaline volcanism, crustal swelling and rifting. Nature, 230:85-87.

LEGARRETA, L.; KOZLOWSKI, E.; BOLLI, A. - 1981 - Esquema estratigráfico y distribución de facies del Grupo Mendoza en el ámbito surmendocino de la Cuenca Neuquina. In: CONGR. GEOL. ARGENTINO, 8, Buenos Aires, 1981. Actas... Buenos Aires. v. 3, p. 389-409.

LEGARRETA, L.; KOKOGIAN, D.; BOGGETTI, D. - s.d. Secuencias deposicionales del Grupo Malargue (Cretácico Superior-Terciario Inferior), Cuenca Neuquina, Argentina. In: CONG. ARGENTINO PALEONT. Y BIOESTRAT., 4, Mendoza, 1986.

LESTA, P.J. \& FERELLO, R. - 1972 - Región extraandina de Chubut y norte de Santa Cruz. In: LEANZA, A.F. ed. Geologia Regional Argentina. Córdoba, Acad. Nac. de Cienc. de Córdoba: 601-653.

LESTA, P.J.; TURIC, M.A.; MAINARDI, E. - 1979 - Actualización de la información estratigráfica en la cuenca del Colorado. In: CONG. GEOL. ARGENTINO, 7, Buenos Aires, 1979. Actas.. Buenos Aires. v. 1, p. 701-713.

LEVI, B. \& AGUIRRE, L. - 1981 - Ensialic spreading-subsidence in the Mesozoic and Paleogene Andes of Central Chile. J. Geol. Soc. London, 138:75-81. 
LLAMBÍAS, E. \& RAPELA, C.W. - 1984 - Las plutonitas y vulcanitas del ciclo eruptivo Gondwánico. In: CONG. GEOL. ARGENTINO, 9, Buenos Aires, 1984. Relatório... Buenos Aires. v. $1(4)$, p. 85-117.

LOCK, B.E. - 1978 - The Cape fold belt of South Africa, tectonic control of sedimentation. Geol. Assoc., Proceedings 89:263-281.

LOCK, B.E. - 1980 - Flat-plate sibduction and the Cape fold belt of South Africa. Geology, 8:35-39.

LOWELL, J. - 1985 - Structural styles in petroleum exploration. Tulsa. Oil and Gas Consultants International Inc. 460 p.

LUDWIG, W.J. et al. - 1980 - Tertiary and Cretaceous paleoenvironments in the southwest Atlantic Ocean, preliminary results of Deep Sea Drilling Project, Leg 71. Geol. Soc. Am. Bull., Part 1, 91:655-664.

MAKSAEV, V. - 1984 - Mesozoico a Paleógeno de la región de Antofagasta. In: Seminario Actualización de la Geología de Chile, Apuntes. Serv. Nac. de Geol. y Min., Santiago. Miscelánea 4:C1-C20.

MALUMIAN, N.; NULlO, F.E.; RAMOS, V.A. - 1983 - The Cretaceous of Argentina, Chile, Paraguay, and Uruguay. In: MOULLADE, M. \& NAIRN, A.E.M. eds. The Phanerozoic Geology of the World II. The Mesozoic B, Elsevier. p. 265-304.

MALVICINI, L. \& LLAMBÍAS,: E.J. - 1982 - El magmatismo Mioceno y las manifestaciones metalíferas asociadas en Argentina. In: CONG. LATINOAM. DE GEOL. ECON., 5, Buenos Aires, 1982. Actas... Buenos Aires. v. 3, p. 547-566.

MANONI, R. - 1985 - Geología del subsuelo de la Cuenca de Beazley. Boletín de Informaciones Petroleras, Tercera Epoca II 4:34-46. Buenos Aires.

MANTOVANI, M.S.M.; MARQUEES, L.S.; DE SOUZA, M.A. CIVETTA, L.; ATALLA, L.; INNOCENTI, F. - 1985 - Trace element and strontium isotope constraints on the origin and evolution of Paraná continental flood basalts of Santa Catarina State (southern Brazil). J. Petrol., (26) Part 1:187-209.

MARSH, J.R. - 1973 - Relationship between transform directions and alkaline igneous rocks lineaments in Africa and South America. Earth Planet. Sci. Letters, 18:317-3223.

MARTIN, H. - 1976 - A geodynamic model for the evolution of the continental margin of southwest Africa. An. Acad. bras. de Cienc., 48:169-177.

MAZZONI, M.M. - 1985 - La Formación Sarmiento y el vulcanismo paleógeno. Asoc. Geol. Argentina, Revista, XL (1-2):60-68. Buenos Aires.

MCBRIDE, S.L.; ROBERTSON, C.R.; CLARK, A.H.; FARRAR, E. 1983 - Magmatic and metallogenetic episodes in the northern tin belt, Cordillera Real, Bolivia. Geol. Runds., 72(2):685-713.

McLACHLAN, I.R. \& McMILLAN, I.K. - 1979 - Review and stratigraphic significance of Southern Cape Mesozoic Paleontology. Trans. Geol. Soc. South Africa, 79(2):197-212.

MENDEZ, V. - 1975 - Estructuras de las provincias de Salta y Jujuy a partil del meridiano $65^{\circ} 30^{\prime}$ oeste, hasta el límite con las repúblicas de Bolivia y Chile. Asoc. Geol. Argentina. Revista, 29 (4):391-424. Buenos Aires.

MINGRAMM, A.; RUSSO, A.; POZZO, A.; CAZAU, B. - 1979 Sierras Subandinas. In: TURNER, J.C.M. coord. SIMP. GEOL. REGIONAL ARGENTINA. Córdoba, Academia Nacional de Ciencias de Córdoba, V. I:95-137.

MITCHUM, R.M., Jr. \& ULIANA, M.A. - 1985 - Seismic stratigraphy of carbonate depositional sequences, Upper Jurassic-Lower Cretaceous, Neuquén Basin, Argentina. In: BERG, O.R, \& WOOLVERTON, D.G. eds. Seismic Stratigraphy II: An integrated approach to hydrocarbon exploration. Am. Assoc. Petrol. Geol. 255-274. (Memoir 39).

MOMBRU, C.A. \& ULIANA, M.A - 1979 - Esquema tectosedimentario de la Cuenca Mesozoica de Mendoza y Neuquén. In: CONG. GEOL. ARGENTINO, 7, Buenos Aires, 1979. Actas... Buenos Aires. v. 2, p. 239-256

MORDOJOVICH, C. - 1981 - Sedimentary basins of the Chilean Pacific offshore. In: HALBOUTY, M.T. ed. Energy resources of the Pacific Region. Am. Assoc. Petrol. Geol. p. 63-82. (Studies in Geology).

MORENO, J.A. - 1970 - Estratigrafía y paleogeografía del Cretácico Superior de la Cuenca del Noroeste Argentino, con especial mención de los Subgrupos Balbuena y Santa Bárbara. Asoc. Geol. Argentina, Revista, 25(1):2-44, Buenos Aires.

MOSCOSO, R. - 1984 - El Mesozoico superior-Cenozoico inferior del sector occidental de las regiones de Atacama y Coquimbo $\left(27^{\circ}-30^{\circ} \mathrm{S}\right)$. Seminario Actualización de la Geología de Chile. Apuntes. Serv. Nac. de Geol. y Min., Santiago, Miscelánea, 4:G1-G20.

MOYA, M.C. \& SALFITY, J.A. - 1982 - Los ciclos magmáticos en el noroeste Argentino. In: CONG. LATINOAM. DE GEOL., 5, Buenos Aires. Actas... Buenos Aires. v. 3, p. 523-536.

MUNIZAGA, F.; JUETE, C.; HERVE, F. - 1985 - Geocronologí $\mathrm{K}-\mathrm{Ar}$ y razones iniciales $\mathrm{Sr}^{87} / \mathrm{Sr}^{86}$ de la "faja Pacífica" de "Desarrollos Hidrotermales". In: CONG. GEOL. CHILENO, 4, Antofagasta, 1985. Actas... Antofagasta. v. 4, p. 4-357, 4-379.
MUÑOZ, J. - 1984 - Geología de la Cordillera Principal de los Andes de Chile entre Talca $\left(35^{\circ}\right.$ L.S.) y Temuco $\left(39^{\circ}\right.$ L.S.). Seminario Actualización de la Geología de Chile. Apuntes. Serv. Nac. de Geol. y Min., Santiago. Miscelánea, 4:N1-N15.

MURRIS, R.J. - 1980 - Middle East: stratigraphic evolution and oil habitat. Am. Assoc. Petrol. Geol. Bull., 64:597-618.

NARANJO, J.A.; PUIG, A.; SUAREZ, M. - 1982 - Nuevos antecedentes estratigráficos del Triásico Superior-Jurásico de la Cordillera de la Costa sector meridional de la región de Antofagasta, Chile. In: CONG. GEOL. CHILENO, 3 , Concepción, 1982. Actas... Concepción. v. 1, p. A189-A206.

NATLAND, M.L.; GONZALEZ, E.; CANNON, A.; ERNST, M. - 1974 - A system of stages for correlation of Magallanes basin sediments. Geol. Soc. Am. p. 126 (Mem. 139).

ORTIZ, A. \& ZAMBRANO, J.J. - 1981 - La provincia geológica Precordillera Oriental. In: CONG. GEOL. ARGENTINO, 8 , Buenos Aires, 1981. Actas... Buenos Aires. v. 3, p. 59-74.

PADULA, E.L. - 1972a - Subsuelo de la Mesopotamia y regiones adyacentes, In: LEANZA, A.F. ed. Geologla Regional Argentina. Acad. Nac. de Cienc., Córdoba, p. 213-235.

PADULA, E.L. - 1972b - Las cuencas sedimentarias petrolíferas argentinas, sus resultados. Fac. de Ing. de Petrol., Univ. Nac. de Cuyo. Mendoza, Conferencia. (Serie G 1).

PASCUAL, R. - 1984 - Evolución de los vertebrados Cenozoicos: sumario de los principales hitos. In: CONG. ARG. DE PALEONT. Y BIOSTRAT., 4, Mendoza, 1984. Actas... Mendoza. v. 2, p. 209-218

PASCUAL, R. \& BONDESIO, P. - 1982 - Un roedor cardiatheriinae (hydrochoeridae) de la edad Huayqueriense (Mioceno tardio) de la Pampa, Sumario de los ambientes terrestres en la Argentina durante el Mioceno. Ameghiniana, 19(102):19-35, Buenos Aires.

PASCUAL, R. et al. - 1965 - Las edades del Cenozoico mamalífero de la Argentina, con especial atención a aquellas del territorio bonaerense, Provincia de Buenos Aires. Com. de Invest. Cient. Anales, VI: 165-193, La Plata.

PEREIRA, M.J.; BARBOSA, C.M.; AGRA, J.; BOSCOGOMES, J.; ARANHA, L.G., F.; SAITO, M.; RAMOS, M.A.; CARVALHO, M.D.; STAMATO, M. - 1986 - Estratigrafia da bacia de Santos: Análise das seqüencias. Sistemas Deposicionais e revisão litoestratigráfica. In: CONGR. BRAS. GEOL. 34, Goiânia, 1986. Anais... Goiânia. v. 1, p. 65-79.

PILGER, R.H. - 1983 - Kinematics of the South American subduction zone from global plate reconstructions, In: Geodynamics of the Eastern Pacific Region, Caribbean and Scotia Arcs, Geodynamics Series, 9:113-125.

PINCHEIRA, M. \& THIELE, R. - 1982 - El Neocomiano de la Cordillera de la Costa de Vallenar $\left(28^{\circ} 15^{\prime}\right.$ a $28^{\circ} 30^{\prime}$ LS): situación tectónica del borde occidental de la cuenca marina neocomiana tras-arco. In: CONG. GEOL. CHILENO, 3, Concepción 1982. Actas... Concepción. v. 1, p. A236-A261.

PLATT, J.P. - 1986 - Dynamics of orogenic wedges and the uplift of high-pressure metamorphic rocks. Geol. Soc. Am. Bull., 97:1037-1053.

RABINOWITZ, P.D. \& LABRECQUE, J. - 1979 - The Mesozoic South Atlantic Ocean and evolution of its continental margin. $J$. Geoph. Res., 84:5973-6002.

RAMOS, V.A. - 1978 - El vuscanismo del Cretácico Inferior de la Cordillera Patagónica de Argentina y Chile. In: CONG. GEOL. ARGENTINO, 7, Buenos Aires. Actas... Buenos Aires. v. 1, p. 423-435.

RAMOS, V.A. - 1982 - Las ingresiones pacíficas del Terciario en el norte de la Patagonia. In: CONG. GEOL. CHILENO, 3, Concepción. Actas... Concepción. v. 1, p. A262-A288.

RAMOS, V.A. - 1983 - Evolución tectónica y metalogénesis de la Cordillera Patagónica. In: CONG. NAC. DE GEOL. ECON., 2, San Juan. Actas..., San Juan. v. 1, p. 107-124.

RAMOS, V.A. - 1985 - El Mesozoico de la alta Cordillera de Mendoza: facies y desarrollo estratigráfico, Argentina. In: CONG. GEOL. CHILENO, 4, Antofagasta. Actas..., Antofagasta. v. 1, p. 1-429 $1-513$.

RAMOS, V.A. \& PALMA, M.A. - 1983 - Las lutitas pizarreñas fosilíferas del cerro Dedo lago La plata, Provincia del Chubut. Asoc. Geol. Argentina, Revista, 38(2):148-160.

RAMOS, V.A.; NIEMEYER, H.; SKARMETA, J.; MUÑOZ, J. - 1982 - The magmatic evolution of the Austral Patagonian Andes. Earth Sci. Rev., 18 (3-4):411-443.

RAMOS, E.D. \& RAMOS, V.A. - 1979 - Los ciclos magmáticos de la República Argentina. In: CONG. GEOL. ARGENTINO, 7, Buenos Aires, 1979. Actas... Buenos Aires. v. 1, p. 771 -786.

RANGEL, H.D.; BISOL, D.L.; GAMBOA, L.A.P.; SOUZA CRUZ C.E. - 1986 - Sobre a ocorrência de anidrita no Eoceno médio da Bacia de Campos e sua relação com variações relativas de nível do mar. In: CONGR, BRAS. GEOL., 34, Goiânia, 1986. Anais... Goiânia, SBG. v. 1, p. 23-35.

RAPELA, C.W.; SPALLETTI, L.; MERODIO, J.; ARAGON, E. 1983 - Evolución magmática y geotectónica de la "Serie Andesítica" Andina (Paleoceno-Eoceno) en la Cordillera 
Norpatagónica. Asoc. Geol. Argentina, Revista, XXXVIII:469-484, Buenos Aires.

RAPELA, C.W.; SPALLETTI, L.A.; MERODIO, J.C.; ARAGON, E. - 1984 - El vulcanismo Paleoceno-Eoceno de la provincia volcánica Andino-Patagónica. In: CONG. GEOL. ARGENTINO, 9, Buenos Aires, 1984. Relatório I, Buenos Aires. v. 8, p. 189-213.

REYES, F.C.; VIRAMONTE, J.G.; GUTIERREZ, W. - 1976 Consideraciones sobre el vulcanismo del Subgrupo Pirgua (Cretácico) en el norte Argentino. In: CONG. GEOL. ARGENTINO, 6, Buenos Aires, 1976. Actas... Buenos Aires. v. 2, p. 205-223.

RICCARDI, A.C. - 1983 - The Jurassic of Argentina and Chile. In: MOULLADE, M. \& NAIRN eds. The Phanerozoic Geology of the World II, the Mesozoic, B., Elsevier, p. 201-263.

RICCARDI, A.C. - 1987 - Cretaceous paleogeography of southern South America. Paleogeogr., Palaeoclimat., Paleoecol, 59:169-195.

RICHARDSON, E.S. \& RONA, P.A. - 1980 - Global Eocene plate reorganization: implications for petroleum exploration. In: ESCAP, CCOP/SOPAC. p. 25-36. (Tech. Bull. 3).

RIVANO, S. - 1984 - Geología del Meso-Cenozoico entre los $31^{\circ}$ y los $33^{\circ}$ lat. sur. Seminario Actualización de la Geología de Chile, Apuntes. Serv. Nac. de Geol. y Min., Santiago. p. K1-K17 (Miscelánea 4).

ROLLERI, E.O. - 1972 - Acerca de la dorsal del Mar Argentino y su posible significado geológico. In: CONG. GEOL. ARGENTINO, 5, Buenos Aires, 1972. Actas... Buenos Aires. v. 4, p. 203-220.

ROLLERI, E.O. \& CRIADO, P. - 1968 - La Cuenca Triásica del norte de Mendoza. In: JORN. GEOL. ARGENTINAS, 3, Buenos Aires, 1968. v. 1, p. 1-60.

RUSSO, A. \& SERRAIOTTO, A. - 1978 - Contribución al conocimiento de la estratigrafía terciaria en el noroeste Argentino. In: CONG. GEOL. ARGENTINO, 7, Buenos Aires. Actas... Buenos Aires, v. 1, p. 715-730.

RUSSO, A.; FERELLO, R.; CHEBLI, G. - 1980 - Llanura Chaco Pampeana. In: TURNER, J.C.M. coord. SIMPOSIO DE GEOLOGÍA REGIONAL ARGENTINA. Córdoba, Acad. Nac. de Cienc. de Córdoba (1): 139-183.

RUST, I.C. - 1975 - Tectonic and sedimentary framework of Gondwana basins in southem Africa, In: CAMPBELL, K.S. ed. Gondwana Geology. Australian Nat. Univ. Press: 537-564.

SALFITY, J.A.; MARQUILLAS, R.; GARDEWEG, M.; RAMIREZ, C.; DAVIDSON, J. - 1985 - Correlaciones en el Cretácico Superior del norte de Argentina y Chile. In: CONG. GEOL. CHILENO, 4, Antofagasta, 1985. Actas... Antofagasta. v. 4, p. 1654-1667.

SALINAS, P. - 1981 - El Terciario lacustre del valle del Lolco (Formación Lolco), IX Región, Chile. In: CONG. GEOL. ARGENTINO, 8, Buenos Aires, 1981. Actas... Buenos Aires. v. 4, p. 471-483.

SCHMIDT, D.L. \& ROWLEY, P.D. - 1986 - Continental rifting and transform faulting along the Jurassic transantarctic rift, Antarctica. Tectonics, 5(2):279-291.

SCHWAB, K. - 1985 - Basin formation in a thickening crust - the intermontane basins in the Puna and the Eastern Cordillera of NW Argentina (central Andes). In: CONG. GEOL. ARGENTINO, 9, Buenos Aires, 1985. Actas... Buenos Aires. v. 2, p. 138-158.

SEELY, D.R. - 1979 - The evolution of structural highs bordering major forearc basins. In: WATKINS, J.S., MONTADER, L., WOOD DICKERSON, P. eds. Geological and geophysical investigations of continental margins. Am. Assoc. Petrol. Geol. p. 245-260. (Memoir 29).

SEMPERE, R. - 1986 - Estratigraffa secuencial del Mesozoico Andino Boliviano. In: Cretácico de America Latina. PICG, Proyecto 242, Primer Simposio: 1986, 72-73. La Paz.

SEMPERE, R.; ARNAUD, M.; LOBO, J.; SUAREZ, R.; BEAUDOIN, B. - 1986 - Descubrimiento de una fauna jurásica en una nueva formación de la región de Cochabamba. In: Cretácico de América Latina. PIGC, Proyecto 242, Primer Simposio: 1986, p. 74. La Paz.

SIEDNER, G. \& MITCHELL, J.G. - 1976 - Episodic Mesozoic volcanism in Namibia and Brazil: a $\mathrm{K}-\mathrm{Ar}$ isochron study bearing on the opening of the South Atlantic. Earth and Plan. Sci. Lett. 30(2): $292-302$.

SIMPSON, E.S.W. - 1977 - Evolution of the South Atlantic. Trans. Geol. Soc. S. Africa, 80:1-15.

SKARMETA, M.J. - 1976a - Evolución tectónica y paleogeográfica de los Andes Patagónicos de Aysén (Chile) durante el neocomiano. In: CONG. GEOL. CHILENO, 1, Santiago, 1976. Actas... Santiago. v. I(B), p. 1-15.

SKARMETA, M.J. - $1976 \mathrm{~b}$ - Estratigrafía del Terciario sedimentario continental de la región central de la provincia de Aysén, Chile. Asoc. Geol. Argentina, Revista, XXXI:73-82. Buenos Aires.

SOARES, P.C. - 1981 - Estratigrafia das formaçōes Jurássico-Cretáceas na bacia do Paraná, Brasil. In: Cuencas sedimentarias del Jurásico y Cretácico de América del Sur. Buenos Aires. Comité Sudamericano del Jurásico y Cretácico, v. 1:271-304.
SPALLETTI, L.A. \& MAZZONI, M.M. - 1977 - Sedimentología del grupo Sarmiento en un perfil ubicado al sudeste del lago Colhue Huapi, Provincia de Chubut. Obra del Centenario del Museo de la Plata, IV:261-284, La Plata.

SUAREZ, M. - 1979 - A late Mesozoic island arc in the southern Andes, Chile. Geol. Mag., 116(3):181-190.

SPRECHMANN, P.; BOSSI, J.; DA SILVA, J. - 1981 - Cuencas del Jurásico y Cretácico del Uruguay. In: Cuencas sedimentarias del Jurásico y Cretácico de América del Sur. Comité Sudamericano del Jurásico y Cretácico, 1:239-270, Buenos Aires.

STIPACINIC, P.N. - 1983 - The Triassic of Argentina and Chile. In: MOULLADE, M. \& NAIRN, A.E. eds. The Phanerozoic geology of the World II. The Mesozoic, B. Elsevier, p. 181-199.

TASCH, P. \& VOLKHEIMER, W. - 1970 - Jurassic conchostracans from Patagonia, Kansas Univ. Paleont. Contribut. p. 1-23. (Paper 50).

TERUGGI, M.E. - 1957 - The nature and origin of Argentine loess. $J$. Sed. Petrol., 27(3):322-332.

THIELE, R. \& HEIN, R. - 1979 - Posición y evolución tectónica de los Andes Nordpatagónicos. In: CONG. GEOL. CHILENO, 2, Actas... v. 1, p. B33-B46.

THIELE, R. \& NASI, C. - 1982 - Evolución tectónica de los Andes a la latitud $33^{\circ}$ a $34^{\circ}$ Sur (Chile Central) durante el Mesozoico-Cenozoico. In: CONG. LATINOAM. DE GEOL., 5 , Buenos Aires, 1982. Actas... Buenos Aires. v. 3, p. 403-426.

THOMAS, Fo, A.; CORDANI, U.G.; KAWASHITA, K. - 1976 Aplicação do método $\mathrm{Rb} / \mathrm{Sr}$ na datação de rochas sedimentares argilosas da Bacia do Paraná. In: CONG. BRAS. GEOL., 29, Ouro Preto, 1976. Anais... Ouro Preto, SBG. v. 4, p. 289-302.

TURNER, J.C.M. \& CAZAU, L.B. - 1979 - Estratigrafía del prejurásico. In: ROLLER, E.O. ed. Geología y recursos naturales del Neuquén. CONG. GEOL. ARGENTINO, 7, Buenos Aires, 1979. Relatório, Buenos Aires. p. 25-36.

TOBISCH, O.T.; SALEEBY, J.B.; FISKE, R.S. - 1986 - Structural history of continental volcanic arc rocks, eastern Sierra Nevada California: a case for extensional tectonics. Tectonics, 5(1):65-94.

ULIANA, M.A. \& BIDDLE, K.T. - 1987 - Permian to Late Cenozoic evolution of northern Patagonia, main tectonic events, magmatic activity, and depositional trends. In: MCKENZIE ed. Gondwana Six: structure, tectonics, and geophysics. AGU Geophysical Monograph 40:271-286.

URIEN, C.M. \& ZAMBRANO, J.J. - 1972 - Estructura de la terraza continental del sur de Brasil y Argentina (Hasta los $49^{\circ}$ de latitud sur). Conference on Solid Earth Problems, V. 11, Symposium on the Results of Upper Mantle Investigations with Emphasis on Latin America, p. 489-500. Buenos Aires.

URIEN, C.M.; ZAMBRANO, J.J.; MARTINS, L.R. - 1981 - The basins of south-eastern South America (Southern Brazil, Uruguay and eastern Argentina), including the Malvinas Plateau and southern South Atlantic paleogeographic evolution. In: Cuencas sedimentarias del Jurásico y Cretácico de América del Sur. Comité Sudamericano del Jurásico y Cretácico, I: 45-125, Buenos Aires.

UYEDA, S. \& KANMORI, H. - 1979 - Back-arc opening and the mode of subduction. J. Geophys. Res., 84:1049-1061.

VALENCIO, D.A. \& VILAS, J.F.A. - 1976 - Sequence of the continental movements occurred prior to and after the formation of the South Atlantic. An. Acad. brasil. Ciênc., 48 (Supl.) 377-386.

VALENZUELA AYALA, E. - 1982 - Estratigrafía de la boca Occidental del canal Chacao, X Región, Chile. In: CONG. GEOL. CHILENO, 3, Concepción, Acta.... Concepción. v. 1, p. A343-A376.

VÁSOUEZ, J. \& GORROÑO, R.A. - 1980 - Límite de la faja plegada de la República Argentina. Asoc. Geol. Argentina, Revista, 35(4):582-585, Buenos Aires.

VERGARA, M. \& DRAKE, R. - 1979 - Edades K/Ar en secuencias volcánicas continentales post Neocomianas de Chile central; su depositación en cuencas intermontanas restringidas. Asoc. Geol. Argentina. Revista, XXXIV(1):42-52.

VERGARA, M. \& LÓPEZ, L. - 1982 - El volcanismo Mioceno y Plioceno entre los $36^{\circ}$ y $40^{\circ}$ L.S. de los Andes Chilenos: Comentario y Revisión. In: CONG. LATINOAM. DE GEOLOGIA, 5, Buenos Aires, 1982. Actas... Buenos Aires. v. 3, p. 513-521.

VERGARA, M. \& MUNIZAGA, F. - 1974 - Age and evolution of the Upper Cenozoic andesite volcanism in Central-South Chile. Geol. Soc. Am. Bull. 85:603-606.

VIVIERS, M.C. - 1986 - Bioestratigrafia e evolução paleoambiental do Meso-Neocretáceo da bacia de Santos. Brasil. In: CONGR. BRAS. GEOL., 34, Goiânia, 1986. Anais... Goiânia, SBG. v. 1, p. 50-64.

WILLIAMS, B.G. \& HUBBARD, R.J. - 1984 - Seismic stratigraphic framework and depositional sequences in the Santos Basin, Brazil. Mar. and Petrol. Geol., 1:90-104.

WILSON, T.J. - 1983 - Stratigraphic and structural evolution of the Ultima Esperanza foreland fold-thrust belt, Patagonian Andes, Southern Chile. Columbia University, New York, 360 p. (Unpub. Ph.D. dissertation).

WINDHAUSEN, A. - 1931 - Geologfa Argentina. Segunda parte, geología histórica y regional del territorio Argentino. Talleres 
Jacobo Peuser, 645 p., Buenos Aires.

WINSLOW, M.A. - 1982 - The structural evolution of the Magallanes Basin and Neotectonics in the southernmost Andes. In: CRADDOCK, C. ed. Antarctic Geoscience. p. 143-154, University of Wisconsin, Madison.

WORSLEY, T.R.; NANCE, D.; MOODY, J.B. - 1984 - Global tectonics and eustasy for the past 2 billion years. Mar. Geol., 58:373-400.

WURSTER, P. - 1965 - Krustenbewegungen, Meerespiegelschwankungen und KlimaLnderungen der deutschen Trias. Geol. Rundsch, 54:224-240.

YRIGOYEN, M.R. - 1969 - Problemas estratigráficos del Terciario de Argentina (Relato). Ameghiniana, VI(4):315-329, Buenos Aires.

YRIGOYEN, M.R. - 1975a - La edad cretácica del Grupo Gigante (San Luis) y su relación con cuencas circunvecinas. In: CONG. ARGENTINO DE PALEONT. Y BIOSTRAT., 1, Tucumán, 1975. Actas... Tucumán. v. 2, p. 29-56.

YRIGOYEN, M.R. - 1975b - Geología del subsuelo y plataforma continental. In: Geología de la Provincia de Buenos Aires. CONG. GEOL. ARGENTINO, 6, Buenos Aires, 1975. Relatorio, Buenos Aires. p. 139-168.
YRIGOYEN, M.R. - 1979 - Cordillera Principal. In: TURNER, J.C.M. coord. Segundo Simposio de Geología Regional Argentina. Acad. Nac. de Cienc. de Córdoba, I:651-694, Córdoba.

YRIGOYEN, M.R. \& STOVER, L. - 1969 - La Palinología como elemento de correlación del Triásico de la Cuenca Cuyana. In: JORN. GEOL. ARGENTINAS, 4, Mendonza, 1969. Actas... Mendonza, v. 2, p. 427-447.

ZAMBRANO, J.J. - 1980 - Comarca de la cuenca Cretácica de Colorado. In: TURNER, J.C.M. coord. Ségundo Simposio de Geologia Regional Argentina. Acad. Nac. de Cienc. de Córdoba. II: $1033-1069$, Córdoba.

ZUZEK, A.B. - 1978 - Descripción geológica de la hoja 18F, Chamical, Provincia de la Rioja. Servicio Geol. Nac., Buenos Aires. (Boletín 161).
MANUSCRITO 495

Recebido em 24 de setembro de 1987 Revisão aceita em 02 de fevereiro de 1988

A tentaçāo é grande para os jovens professores recém-formados, e por vezes brilhantes, de deslumbrar seus alunos, para subjugá-los e conquistar uma admiração sem reserva. Mas ensinar não É subjugar, o verdadeiro processo didático é outro. O educador deve escutar para informarse sobre as motivaçōes didáticas de seus alunos, seus interesses pessoais, a fim de poder dialogar com cada um. 